\title{
An energy and exergy analysis of biomass gasification integrated with a char-catalytic tar reforming system
}

\section{David Buentello-Montoya ${ }^{\mathrm{a}}$, Xiaolei Zhang ${ }^{\mathrm{b} *}$}

aSchool of Mechanical and Aerospace Engineering, Queen's University Belfast, Belfast BT9 5AH, United Kingdom.

${ }^{b}$ Department of Chemical and Process Engineering, University of Strathclyde, Glasgow G1 1XJ, United Kingdom *Corresponding author: Tel.: +44(0) 141548 4131, E-mail address: xiaolei.zhang@strath.ac.uk, Address: 75 Monrose St G1 1XJ, Glasgow, United Kingdom.

\begin{abstract}
Adequate tar removal is a recurrent challenge for biomass gasification. Materials such as char and activated char are promising catalysts for tar reforming because of their activity, inexpensiveness and constant production during gasification. Although the behaviour of char and activated char as catalyst has been previously studied, an evaluation of the thermodynamic efficiencies of the tar reforming process using char as a catalyst still lacking. This work analyses the performance of a two-stage system, where gasification is followed by tar reforming using char catalysts. For the study, a model based in a combination of equilibrium thermodynamics and chemical kinetics was developed. The first stage, where gasification occurs, was simulated with a thermodynamic equilibrium model. Gasification equilibrium models available in literature only predict the fractions of $\mathrm{H}_{2}, \mathrm{CO}, \mathrm{CO}_{2}$ and $\mathrm{CH}_{4}$; the model developed for this work also predicts the formation of three model tar with different characteristics (benzene, toluene and naphthalene), providing information on the stability of formed tar. The second stage, simulated using kinetics from literature, consists on reforming the tar with catalysts made of residual char. The effects of the reactor temperature, equivalence ratio, and residence time were assessed via the gas quality, based on the gas lower heating value and tar concentration, and process efficiency, based on the energy and exergy efficiencies. Results showed that using char or activated char catalysts increases the heating value of the gas while reducing its tar concentration. Moreover, the process benefits thermodynamically (i.e. less exergy is destroyed) from low gasification temperatures and high reforming temperatures. Simulations indicate that a tarless gas with a lower heating value of more than $8 \mathrm{MJ} / \mathrm{Nm}^{3}$ can be produced from gasification at $1023 \mathrm{~K}$ with an equivalence ratio of 0.15 and subsequent reforming at $1123 \mathrm{~K}$ with a residence time in the catalyst bed of 1 second.
\end{abstract}

Keywords: Thermodynamic equilibrium model, Tar reforming, Char catalyst, Gasification, Exergy analysis

\section{Number of words: 4535}

\section{Introduction}

During biomass gasification a feedstock is partially oxidized with steam, oxygen or $\mathrm{CO}_{2}$ to produce an energy-dense gas consisting on $\mathrm{H}_{2}, \mathrm{CO}, \mathrm{CO}_{2}, \mathrm{CH}_{4}$ and other species in a lesser (but not negligible) 
extent ${ }^{1}$. The produced gases can be either used for power generation or upgraded via processes such as Fischer-Tropsch synthesis or methane synthesis ${ }^{2,3}$. Gasification has been a subject of study for decades, leading to the development of different types of gasifiers varying from simple designs, such as fixed bed gasifiers, to advanced designs, such as plasma gasifiers, each with their own advantages and disadvantages ${ }^{4}$. However, for most of the commercially available technologies, a recurrent problem lies in the formation of tar, a mixture of condensable hydrocarbons that cause operational issues and needs to be removed.

Even if high gasification temperatures prevent the formation of tar, some operational problems arise under such conditions, as for example pollutants such as HCN are formed, and in the case of fluidized bed gasifier, high temperatures lead to bed melting and fluidization problems, making alternative treatments necessary ${ }^{5,6}$. While tar can be catalytically reformed at moderate temperatures (around 700 ${ }^{\circ} \mathrm{C}$ ) with commercial catalysts such as nickel, the catalysts are prone to deactivation and require constant replacement, leading to increases in operation costs and decreases in efficiency ${ }^{7-9}$.

On the other hand, biochar is a byproduct from gasification, whose yield normally varies between 1 and $30 \mathrm{~g}$ per $\mathrm{Nm}^{3}$ of produced gas ${ }^{10}$. Biochar (referred to as char from here onwards) and related carbonbased materials can be used as catalyst for tar reforming ${ }^{11}$. Under adequate conditions, chars can reform the tar into $\mathrm{H}_{2}$ and $\mathrm{CO}$, effectively upgrading the quality of the gas. Studies have shown that at sufficiently high temperatures, char can provide tar conversions as high as those provided by commercial catalysts ${ }^{12}$, and under an adequate atmosphere e.g. steam, chars are not deactivated as quickly as commercial catalysts during reforming ${ }^{13}$. Moreover, since the chars would otherwise end up as waste, their cost as a catalyst is much less than that of commercial counterparts ${ }^{12-14}$. Therefore, incorporating the residual chars as a catalyst to upgrade the syngas can potentially improve the overall biomass gasification process.

Although extensive research has been undertaken to explore the potential of char as a catalyst for tar reforming, so far no work has been conducted that systematically evaluates the performance of a twostage reactor for biomass gasification and catalytic reforming of tar using char or activated char. This work contributes to knowledge by providing an analysis of a two-stage gasifier with catalytic tar reforming in terms of gas quality and process efficiency, with the aim of improving the performance of biomass gasifiers using char catalysts, and ultimately increasing the economic feasibility of the process. Simulations were conducted to theoretically analyze the effect of gasification and reforming parameters in the lower heating value and tar contents of the gas. For the analysis of the process efficiency, the first and second law efficiencies were calculated as an indicator of the process performance. From the analysis, a set of effective operation conditions where the process is thermodynamically favoured is presented. Finally, closing words come in the form of a summary of the work and conclusions from the findings. 


\section{Model description}

The theoretical reactor simulated in this work is portrayed in Figure 1. Compared to the conventional gasifier design (Figure 1a), the theoretical reactor simulated in this work incorporates char particles after gasification for tar reforming (Figure 1b). The two stages of the reactor were simulated separately. The first stage (gasification) was modelled based on a pseudo-stoichiometric thermodynamic equilibrium model. The model was deemed pseudo-stoichiometric because of the two steps undertaken for the calculation of the product gas composition: (1) an stoichiometric calculation based on mass and energy balances, used to predict the yield of $\mathrm{H}_{2}, \mathrm{CO}, \mathrm{CO}_{2}, \mathrm{CH}_{4}$, tar, char and steam (from moisture), and (2) a non-stoichiometric calculation based on the minimization of Gibb's free energy, used to predict the tar distribution. Reported equilibrium models for gasification use a reaction scheme that either neglects the formation of $\operatorname{tar}^{15-17}$ or incorporate tar as a single model compound (usually benzene) ${ }^{18,19}$; these studies only present a general guidance on the amount of tar formed during gasification and any information on the relative stability of the tar species can be very inaccurate. In contrast, the model developed for this work is able to predict the distribution of tar into three species representative of different tar classes: benzene $\left(\mathrm{C}_{6} \mathrm{H}_{6}\right)$, toluene $\left(\mathrm{C}_{7} \mathrm{H}_{8}\right)$ and naphthalene $\left(\mathrm{C}_{10} \mathrm{H}_{8}\right)^{20}$. The output from the first stage was set as the input for the second stage (tar reforming) which was simulated using a kinetic approach.
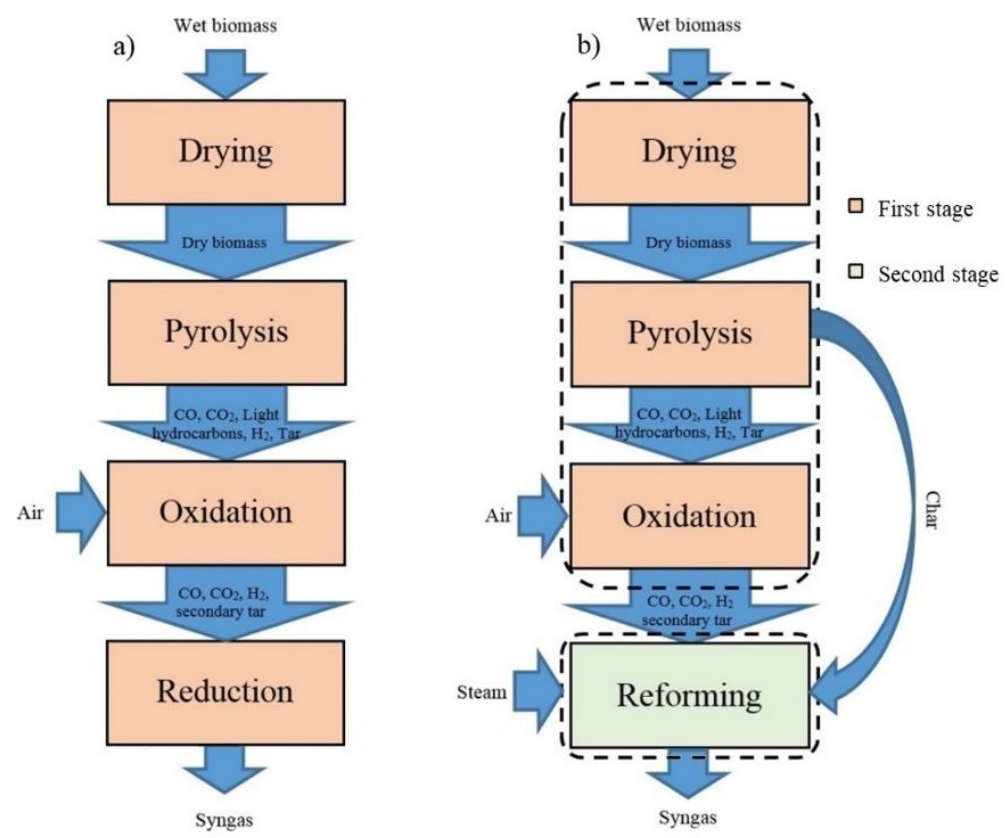

Figure 1. Scheme outlining the two-stage reactor. a) is a conventional downdraft gasifier while b) is the theoretical reactor modelled in this work.

A detailed description of the models for gasification and tar reforming is found in sections 2.1 and 2.2, respectively. The two stages were validated separately by reproducing experiments to an agreement. Calculations of the gas quality and the process efficiency were done based on mass, energy 
and exergy balances, as portrayed in Figure 2. Mass and energy balances are found in Figure 2a, whereas Figure 2b shows the exergy balance. As seen in Figure 2, the unconverted char formed during gasification can be used as a catalyst during reforming, therefore the shown diagram does not reflect the mass balance in the case where no catalyst is employed.

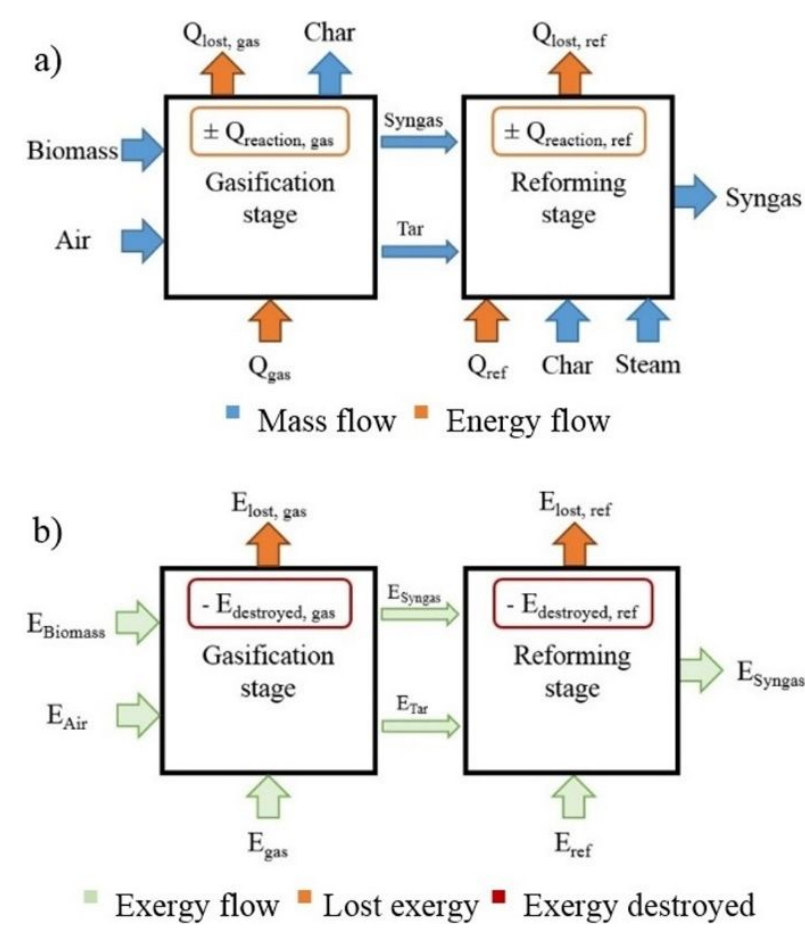

Figure 2. Mass, energy and exergy balances for the modelled reactor. Sub-indexes " $g a s$ " and " $r e f$ " stand for gasification and reforming, respectively. (a) are the mass and energy balances, and (b) is the exergy balances of the system.

2.1. Gasification model. The theoretical limits of the chemical species distribution during chemical reactions can be determined at thermodynamic equilibrium. Thermodynamic equilibrium can be assumed in gasifiers with a sufficiently long residence time, such as downdraft and some fluidised bed gasifiers ${ }^{7}$. Some simplifications and assumptions were accounted for during the simulations:

- In every simulation (excluding the validation cases, where the composition was that of the biomass from the respective study), the composition of the biomass was based on values for wood from a reference ${ }^{21}: 51.0,6.0,42.4$ and $0.1 \%$ wt. for $\mathrm{C}, \mathrm{H}, \mathrm{O}$, and $\mathrm{N}$, respectively, while the moisture content was set as $7.4 \%$ wt.

- Since the amounts of nitrogen and sulfur in the biomass are negligible when compared to carbon, hydrogen and oxygen, related species were not considered as products from gasification. Moreover, the ashes were also ignored in the reactions.

- The tar formed was a mixture of three popularly employed model compounds: benzene, toluene and naphthalene ${ }^{20}$.

- The gases produced during gasification were considered ideal gases.

- Devolatilization of the biomass occurred instantaneously. 
- As the system was assumed to be at thermodynamic equilibrium, the reactor was considered isothermal and any pressure drops were neglected. The heat losses through the reactor walls were considered as $20 \%$ of the total heat in the reactor as an inefficient scenario to simplify the simulation of heat transfer through reactor walls ${ }^{22}$.

The stoichiometric calculation was performed using Python scripting, whereas the non-stoichiometric component was handled by the computational chemistry suite Cantera ${ }^{23}$. While the stoichiometric calculation largely defines the product composition, it only works with a single tar species due to the algebraic nature of the methodology. Hence, the intermediary species benzene, which is always present in tar lumps, was assumed to be produced during gasification and led to the formation of toluene and naphthalene ${ }^{20}$. The percentage composition of the three tar was calculated using the well-documented Gibb's free energy minimization method ${ }^{24}$. The methodology to simulate the two-stage reactor, illustrated in Figure 3, has the advantage of providing more information on the physicochemical properties of the produced tar than models employing a single tar species ${ }^{18,25}$.

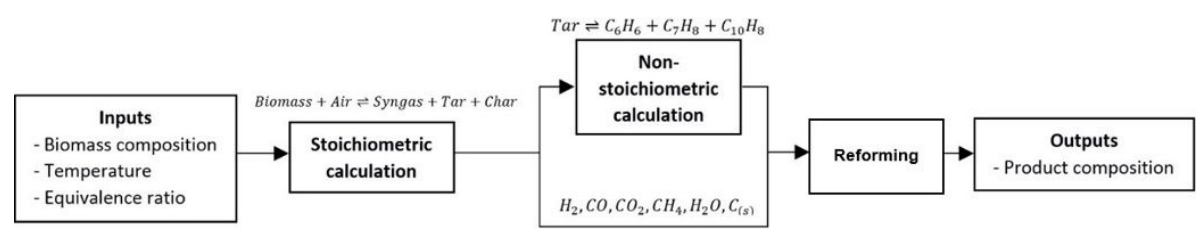

Figure 3. Flowchart of the methodology followed for the simulations.

2.1.1. Stoichiometric calculation. The stoichiometric calculation was done by solving a system of equations defined from the mass and energy balance as well as equilibrium constants.

The stoichiometric calculation followed the global reaction:

$\mathrm{CH}_{\alpha} \mathrm{O}_{\beta}+\gamma\left(\mathrm{O}_{2}+3.76 \mathrm{~N}_{2}\right) \rightleftharpoons x_{1} \mathrm{H}_{2}+x_{2} \mathrm{CO}+x_{3} \mathrm{CO}_{2}+x_{4} \mathrm{CH}_{4}+x_{5} \mathrm{C}_{6} \mathrm{H}_{6}+x_{6} \mathrm{H}_{2} \mathrm{O}+\phi \mathrm{C}+3.76 \gamma \mathrm{N}_{2}$

where $\alpha$ and $\beta$ were defined from the ultimate analysis of biomass, $\gamma$ is the molar quantity of air introduced to the gasifier, $x_{i}$ are the molar quantities of products from gasification and $\phi$ is the molar amount of unconverted char, calculated from a relationship proposed by Lim et al ${ }^{16}$ :

$\phi=0.901+0.439\left(1-e^{-E R+0.0003 T_{\text {gas }}}\right)$

where $E R$ is the equivalence ratio in the gasifier, defined as the ratio of actual fuel/air and the stoichiometric fuel/air ratio, and $T_{\text {gas }}$ is the gasification temperature, in $\mathrm{K}$.

Elemental balances for carbon, hydrogen and oxygen, as well as equilibrium reactions were used to calculate the stoichiometric coefficients of the species. Due to the operation temperatures $\left(T_{\text {gas }} \geq 700\right.$ $\left.{ }^{\circ} \mathrm{C}\right)$, the water-gas shift, carbon gasification and methanation reactions were suitable ${ }^{20}$.

2.1.2. Non-stoichiometric calculation. Based on the principles of thermodynamics, the mass of the single tar species (benzene), calculated from the stoichiometric model, reacts to form toluene and 
naphthalene. Cantera was employed for the free energy minimization calculations ${ }^{23}$. The Gibb's free energies were calculated from its thermodynamic definition and the Shomate relationships ${ }^{24,26}$.

2.1.3. Energy balance. The energy balance for the gasification reaction was defined as:

$\Delta H_{\text {biomass }}^{0}+\gamma\left(\Delta H_{O_{2}}+3.76 \Delta H_{N_{2}}\right)=\sum_{i=1}^{6} x_{i} \Delta H_{i}+Q_{\text {lost }}$

where $\Delta H_{i}$ are the changes in enthalpy of species $i, \Delta H_{\text {biomass }}^{0}$ is the heat of formation of the biomass at $298 \mathrm{~K}$ and $Q_{\text {lost }}$ is any heat lost through reactor walls. The changes in enthalpy for species i were defined as:

$\Delta H_{i}=\Delta H_{i}^{0}+C_{p, i}\left(T_{g a s}-T_{a t m}\right)$

where $C_{p, i}$ is the specific heat at constant pressure for species $i$ and $T_{a t m}$ is the ambient temperature. While the $\Delta H_{i}^{0}$ for the products can be found in tables and textbooks ${ }^{27}$, the heat of formation for the biomass, $\Delta H_{\text {biomass }}^{0}$, can be calculated following the relationship ${ }^{16}$ :

$\Delta H_{\text {biomass }}^{0}=\Delta H_{C O_{2}}^{0}+\frac{\alpha}{2} \Delta H_{H_{2} O}^{0}+(12+\alpha+16 \beta) L H V_{\text {biomass }}$

$L H V_{\text {biomass }}=34.835 w_{C}+93.87 w_{H}-10.8 w_{O}+6.28 w_{N}+10.465 w_{S}$

where $L H V_{\text {biomass }}$ is the biomass lower heating value $(\mathrm{MJ} / \mathrm{kg})$ and $w_{C}, w_{H}, w_{O}, w_{N}$ and $w_{S}$ are the mass fractions of carbon, hydrogen, oxygen, nitrogen and sulfur from the biomass, obtained from the ultimate analysis of the biomass.

2.1.3. Process performance parameters. The syngas LHV was calculated as a function of its components, while the Cold Gas Efficiency (CGE) was calculated from the lower heating values:

$$
\begin{aligned}
& L H V_{\text {syngas }}=4.18\left(2.57 y_{\mathrm{H}_{2}}+3.0 y_{\mathrm{CO}}+8.54 y_{\mathrm{CO}_{2}}+15.13 y_{\mathrm{CH}_{4}}\right) \\
& C G E=\frac{L H V_{\text {syngas }}}{L H V_{\text {biomass }}}
\end{aligned}
$$

where $y_{i}$ is the dry mole fraction of species $i$.

On the other hand, the Carbon Conversion Efficiency (CCE) was calculated by dividing the moles of carbon in the outlet of the reactor by the moles of carbon in the biomass:

$\mathrm{CCE}=\frac{x_{\mathrm{CO}}+x_{\mathrm{CO}_{2}}+x_{\mathrm{CH}_{4}}}{x_{C, \text { biomass }}}$

where $x_{i}$ are the moles of species $i$. 
2.2. Tar reforming model. The tar reforming was simulated as a fixed-bed reactor in one dimension using Cantera ${ }^{23}$, with steam as the reforming agent. The reactor was assumed as a plug-flow isothermal reactor. The kinetics were simulated following the Arrhenius equation:

$-r_{i}=k C_{i}$

$k=k_{0} e^{-E a / R T}$

where $r_{i}$ and $C_{i}$ are the reaction rate and concentration for tar species $i$, respectively, $k$ is the apparent reaction rate constant, $k_{0}$ is the pre-exponential factor, $E_{a}$ is the activation energy, $R$ is the ideal gas constant and $T$ is gas temperature. Species conversion and the apparent rate constant as a function of conversion were calculated as:

$$
\begin{aligned}
& X_{i}=\frac{C_{i, \text { in }}-C_{i, \text { out }}}{C_{i, \text { in }}} \\
& \frac{d X_{i}}{d t}=k\left(1-X_{i}\right)
\end{aligned}
$$

where $X_{i}$ is the conversion of the species it, $C_{i, \text { in }}$ and $C_{i, \text { out }}$ are the concentrations of species " $i$ " at the inlet and the outlet of the reforming stage, respectively, and $t$ is the gas residence time inside the catalyst bed, defined as:

$$
t=C_{i, i n} \int_{0}^{X_{i, \text { out }}} \frac{d X_{i}}{-r_{i}}
$$

where $X_{i, \text { out }}$ is the conversion of the species $i$ at the outlet of the reactor.

The reactions considered in the simulations in the reforming stage along with their respective kinetic parameters are found in Table $\mathbf{1 .}$

Table 1. Chemical kinetic parameters involved in the reforming simulations.

\begin{tabular}{lccc}
\hline \multicolumn{1}{c}{ Reaction } & $\mathbf{k}_{\mathbf{0}}$ & $\begin{array}{c}\mathbf{E}_{\mathbf{a}}, \\
\mathbf{k J} / \mathbf{m o l}\end{array}$ & Ref. \\
\hline \hline $\mathrm{H}_{2}+\mathrm{CO}_{2} \longrightarrow \mathrm{CO}+\mathrm{H}_{2} \mathrm{O}$ & $1.263 \times 10^{4}$ & 473 & 28 \\
$\mathrm{CO}+\mathrm{H}_{2} \mathrm{O} \rightarrow \mathrm{H}_{2}+\mathrm{CO}_{2}$ & $2.778 \times 10^{2}$ & 126 & 28 \\
$\mathrm{CH}_{4}+\mathrm{H}_{2} \mathrm{O} \rightarrow \mathrm{CO}+3 \mathrm{H}_{2}$ & $3.1 \times 10^{3}$ & 125 & 29 \\
$\mathrm{C}_{6} \mathrm{H}_{6}+6 \mathrm{H}_{2} \mathrm{O} \rightarrow 9 \mathrm{H}_{2}+6 \mathrm{CO}$ & $4.4 \times 10^{8}$ & 220 & 30 \\
$\mathrm{C}_{6} \mathrm{H}_{6}+6 \mathrm{H}_{2} \mathrm{O} \rightarrow 9 \mathrm{RC}_{2}+6 \mathrm{CO}$ & $9.79 \times 10^{7}$ & 162 & 31 \\
$\mathrm{C}_{6} \mathrm{H}_{6}+6 \mathrm{H}_{2} \mathrm{O} \rightarrow 9 \mathrm{AC}_{2}+6 \mathrm{CO}$ & $1.98 \times 10^{7}$ & 144 & 31 \\
$\mathrm{C}_{7} \mathrm{H}_{8}+\mathrm{H}_{2} \mathrm{O} \rightarrow 2 \mathrm{H}_{2}+\mathrm{CO}+\mathrm{C}_{6} \mathrm{H}_{6}$ & $3.3 \times 10^{10}$ & 247 & 30 \\
$\mathrm{C}_{7} \mathrm{H}_{8}+\mathrm{H}_{2} \mathrm{O} \stackrel{R C}{\rightarrow} 2 \mathrm{H}_{2}+\mathrm{CO}+\mathrm{C}_{6} \mathrm{H}_{6}$ & $2.51 \times 10^{8}$ & 160 & 31 \\
$\mathrm{C}_{7} \mathrm{H}_{8}+\mathrm{H}_{2} \mathrm{O} \stackrel{\mathrm{AC}}{\rightarrow} 2 \mathrm{H}_{2}+\mathrm{CO}+\mathrm{C}_{6} \mathrm{H}_{6}$ & $3.27 \times 10^{6}$ & 118 & 31
\end{tabular}




$$
\begin{array}{llll}
\mathrm{C}_{10} \mathrm{H}_{8}+4 \mathrm{H}_{2} \mathrm{O} \rightarrow 5 \mathrm{H}_{2}+4 \mathrm{CO}+\mathrm{C}_{6} \mathrm{H}_{6} & 5.6 \times 10^{15} & 360 & 30 \\
\mathrm{C}_{10} \mathrm{H}_{8}+4 \mathrm{H}_{2} \mathrm{O} \stackrel{R C}{\rightarrow} 5 \mathrm{H}_{2}+4 \mathrm{CO}+\mathrm{C}_{6} \mathrm{H}_{6} & 2.21 \times 10^{8} & 159 & 31 \\
\mathrm{C}_{10} \mathrm{H}_{8}+4 \mathrm{H}_{2} \mathrm{O} \stackrel{A C}{\rightarrow} 5 \mathrm{H}_{2}+4 \mathrm{CO}+\mathrm{C}_{6} \mathrm{H}_{6} & 2.68 \times 10^{5} & 95.7 & 31
\end{array}
$$

RC: Catalysed by regular char. AC: Catalysed by activated char

2.3. Exergy analysis. The exergy analysis provides information on the maximum available work from a determinate process while accounting for irreversibilities. The exergies of the species were calculated from the following equations ${ }^{27}$ :

$E_{\text {total }, i}=E_{\text {phys }, i}+E_{\text {chem }, i}$

$E_{\text {phys }, i}=x_{i}\left(\left(h-h_{0}\right)-T_{0}\left(s-s_{0}\right)\right)$

$E_{\text {chem }, i}=x_{i}\left(e_{i}^{\text {chem }}+R T_{0} \ln \left[n_{i}\right]\right)$

where $E_{\text {total, },}, E_{\text {phys }, i}$ and $E_{\text {chem }, i}$ are total, physical and chemical exergies of species i, respectively, $h$ is the enthalpy, $s$ is the entropy, $e_{i}^{\text {chem }}$ is the standard chemical exergy of species $i$, and $n_{i}$ is the molar fraction of species $i$; the sub index 0 denotes reference state. The exergy of the biomass was calculated as a function of its composition following the relationship reported by Szargut ${ }^{32}$ :

$E_{\text {biomass }}=\theta L H V_{\text {biomass }}$

$\theta=\frac{1.0414+0.0177\left(\frac{H}{\bar{C}}\right)-0.3328\left(1+0.0537\left(\frac{H}{\bar{C}}\right)+0.0493\left(\frac{N}{\bar{C}}\right)\right)}{1-0.4021\left(\frac{O}{\bar{c}}\right)}$

The exergy efficiency of the process was calculated for each stage by dividing the exergy of the product gas at the outlet of the reactor by the exergy streams at the reactor inlets. In other words,

$\eta_{E}=\frac{E_{\text {products }}}{E_{\text {reactants }}+E_{\text {gas }}+E_{\text {heat }}}$

$E_{\text {products }}=E_{\text {total, } \mathrm{H}_{2}}+E_{\text {total, } \mathrm{CO}}+E_{\text {total, } \mathrm{CO}_{2}}+E_{\text {total, } \mathrm{CH}_{4}}+E_{\text {total,tar }}+E_{\text {total, } \mathrm{H}_{2} \mathrm{O}}+E_{\text {total, } \mathrm{C}}$

$E_{\text {gas }}$ refers to either the exergy of air or steam, depending on the stage, $E_{\text {reactants }}$ is either the exergy of the biomass (in the gasifier) or the syngas (in the reformer) and $E_{\text {heat }}$ is the physical exergy added when external heating is necessary to achieve a certain temperature. $E_{\text {heat }}$ changes in sign (i.e. physical exergy is extracted) whenever the reforming stage occurs at a lower temperature than gasification.

Finally, the exergy destroyed is defined as the difference between the exergies that enter and exit a reactor:

$E_{\text {destroyed }}=E_{\text {in }}-E_{\text {out }}-E_{\text {lost }}$ 
where $E_{\text {in }}$ is the exergy at the inlet of the reactor, $E_{\text {out }}$ is the exergy of the gas at the outlet of a reactor and $E_{\text {lost }}$ is the exergy lost to the surroundings. The $E_{i n}$ term accounts for all the exergy streams at the inlet of the reactor. For the gasification stage, the $E_{i n}$ term is the exergy of the biomass, externally added heat and the gasification agent. On the other hand, for the reforming stage, $E_{\text {in }}$ includes the exergy of the produced gas, heat supply (if necessary) and the exergy contents of the supplied steam.

\section{Model validation}

3.1. Gasification model. To validate the gasification model, 20 experiments from 8 different references ${ }^{16,33-39}$ were simulated, each under its own set of conditions (e.g. biomass composition, gasification temperature, equivalence ratio, etcetera). The experiments simulated for validation included fluidised bed gasifiers ${ }^{16,33,36,37}$ and downdraft gasifiers $^{34,35,38,39}$. Since the number of experiments replicated was relatively large, values for the mean absolute error were used for validation. Agreement was found between the simulations and references, as seen in Table 2.

Table 2. Error values obtained from simulations using the gasifier model ${ }^{a}$.

\begin{tabular}{ccc}
\hline Species & Mean Absolute Error & Standard Deviation \\
\hline \hline $\mathrm{H} 2$ & 3.647 & 3.340 \\
$\mathrm{CO}$ & 1.835 & 2.324 \\
$\mathrm{CO} 2$ & 2.771 & 3.882 \\
$\mathrm{CH} 4$ & 1.985 & 2.263 \\
Tar* & 4.783 & 8.320 \\
Char* & 0.013 & 2.032 \\
$a$ In \% composition. *In $\mathrm{g} / \mathrm{Nm}^{3}$ &
\end{tabular}

Although the error for the tar species appears larger than the rest, a larger error is unavoidable due to the variability in the composition of the tar species for each experiment. Additional simulations were undertaken to validate the non-stoichiometric component of the model. Experiments from references were simulated for this end ${ }^{37,40}$. The experiments from Kinoshita et al. ${ }^{40}$, where the tar composition as a function of temperature and equivalence ratio was tested, were reproduced. The results can be seen in Figure 4. 


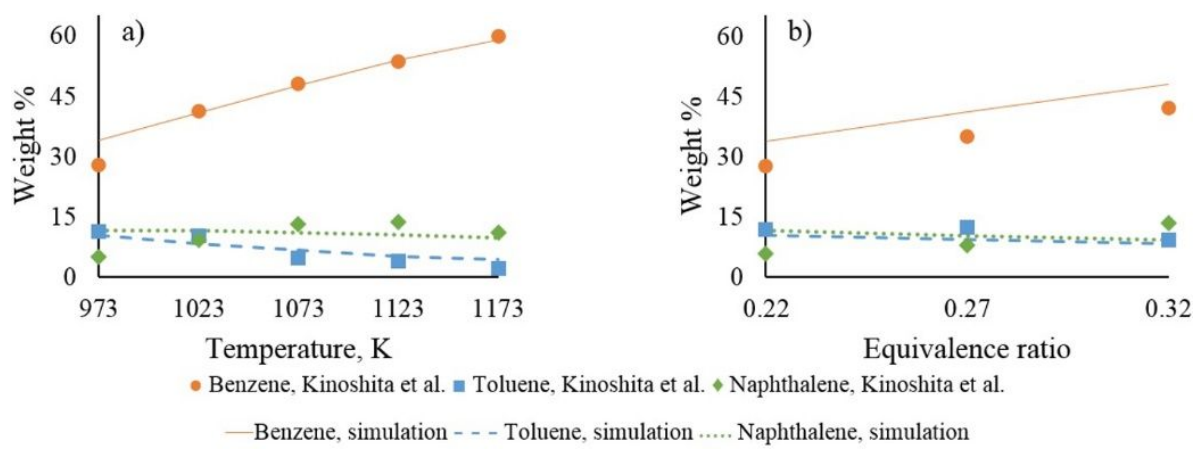

Figure 4. Comparison between simulations and experiments reported by Kinoshita et al. ${ }^{40}$. Tar distribution as a function of temperature (a), and equivalence ratio (b).

3.2. Reforming model. Validation of the kinetic mechanism for tar reforming was done by reproducing experiments documented elsewhere ${ }^{31}$. Briefly, simulated syngas with a mixture of benzene, toluene and naphthalene was injected into a drop tube furnace containing a bed of either char or activated char as and subject to reforming at 650,750 and $850^{\circ} \mathrm{C}$ and residence time of approximately 0.5 seconds. The experiments were simulated and agreement was found between the experiments and simulations for every case, as shown in Figure 5.

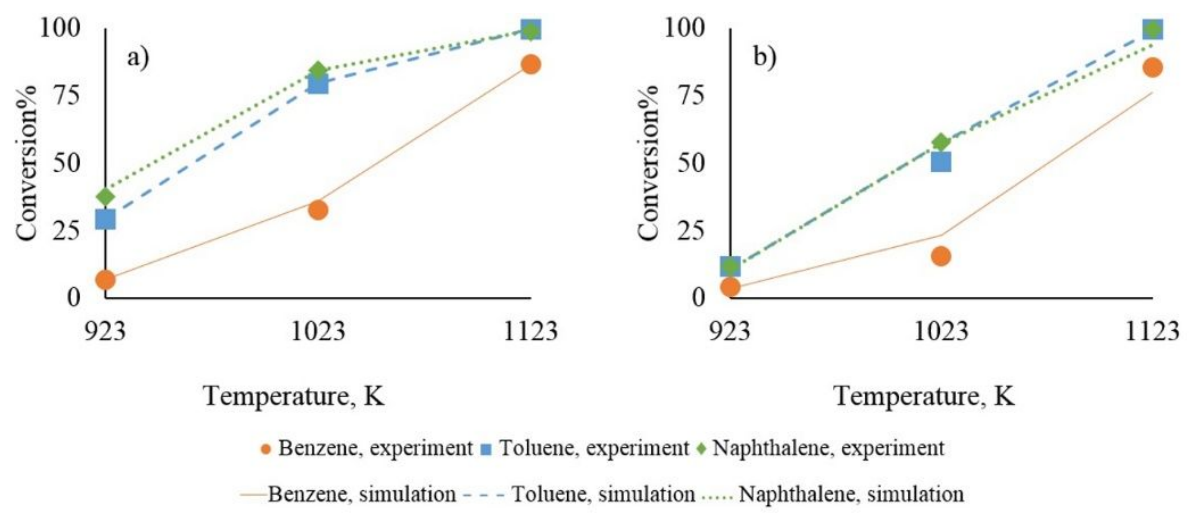

Figure 5. Conversion results from computational simulations. Comparison of experimental and simulation results using a) activated and b) regular char.

\section{Results and discussion}

The two-stage reactor was simulated under different operation conditions to determine the effect of thermophysical parameters in the process. Section 4.1 presents an analysis of the syngas quality (based on the gas LHV and tar contents) using char and activated char as catalysts, while section 4.2 assesses the process efficiency based on the CGE, CCE and exergy efficiencies.

The parameters varied were gasification temperature (923-1123K), reforming temperature (923$1523 \mathrm{~K})$, gasification equivalence ratio ( $0.15-0.45)$ and reforming residence time ( $0.1-1$ seconds). The temperatures investigated in the simulations cover a range such that the theoretical catalyst bed should not suffer from sintering, while the equivalence ratios used are common operation values ${ }^{5,10}$. On the other hand, the values used for temperature and residence time in the reforming reactor are based on 
experimental findings ${ }^{31}$. The amount of steam injected for reforming was not varied because studies have shown that it has a little effect in the reforming of $\operatorname{tar}^{13,41,42}$, and is thereby set at a constant value of $10 \%$ of the total gas volume in the reforming stage.

\subsection{Analysis of the syngas quality}

4.1.1 Effect of the reaction temperature and equivalence ratio. Results from simulations using char (RC), activated char (AC) and no catalyst are found in Figure 6. Figure 6a and $6 \mathbf{b}$ show the gas lower heating value and tar contents as a function of gasification temperature and reforming temperature, respectively. The simulations from Figure 6a were conducted with constant values for the equivalence ratio, reforming reactor temperature and residence time of $0.25,1023 \mathrm{~K}$ and 0.5 seconds, respectively. When catalysts are used, the gas lower heating value increased and the tar contents decreased when compared with the case without catalyst. During reforming, the activated char performed better than the regular char, providing larger increases in LHV and reductions in tar contents. However, the difference between the catalysts becomes negligible at high temperatures when there are no tar in the gas produced from gasification.

During the simulations performed to develop Figure $\mathbf{6 b}$, the gasification temperature and equivalence ratio were held constant at $923 \mathrm{~K}$ and 0.25 , respectively; the values were chosen to ensure not all the tar was not decomposed by oxidation with air. When using char and activated char, the tar were almost completely reformed at around $1173 \mathrm{~K}$, whereas complete thermal cracking required more than $1523 \mathrm{~K}$. On the other hand, the LHV reached a maximum value (around $7.2 \mathrm{MJ} / \mathrm{Nm}^{3}$ under the studied conditions), which is a function of the equivalence ratio, regardless of the employed catalyst.
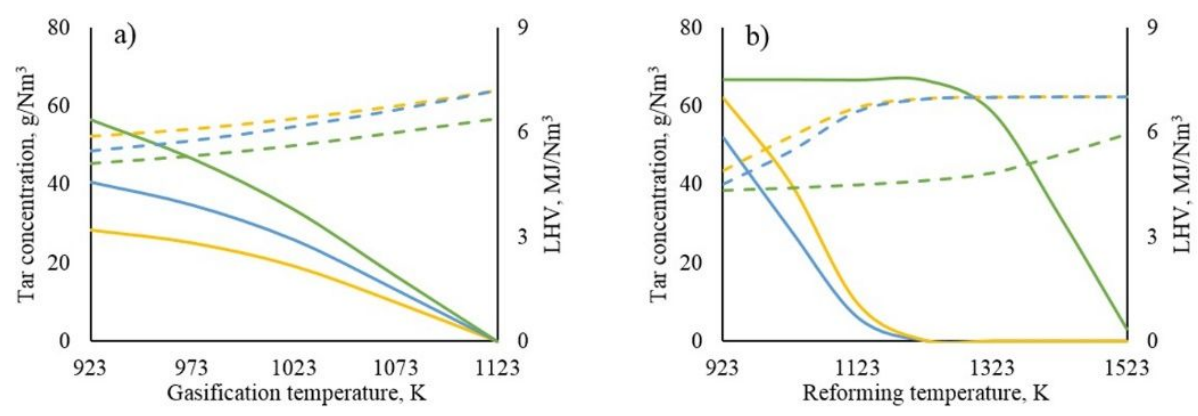

- Tar, RC — Tar, AC — Tar, No catalyst - - - LHV, RC - - LHV, AC - - - LHV, No catalyst

Figure 6. Tar concentration $\left(\mathrm{g} / \mathrm{Nm}^{3}\right)$ and Lower Heating Value $\left(\mathrm{MJ} / \mathrm{Nm}^{3}\right)$ and as a function of temperature (a) gasification temperature during reforming at $1023 \mathrm{~K}$ and (b) reforming temperature during gasification at $923 \mathrm{~K}$. For both cases the residence time and equivalence ratios were 0.5 seconds and 0.25 , respectively.

The effect of the equivalence ratio in the LHV and tar contents in the produced gas using char and activated char is found in Figure 7. Figure 7a corresponds to the tar concentration while Figure 7b corresponds to the LHV of the gas. Increasing the reforming temperature decreased the tar contents and increased the LHV. On the other hand, although while increasing the ER decreased the contents of tar in the gas, the LHV also decreased significantly because the gas became diluted with the $\mathrm{N}_{2}$ from air. 
Due to the abrupt decrease in the LHV with increasing the ER, high ERs are not desirable even if they result in lower tar yields.

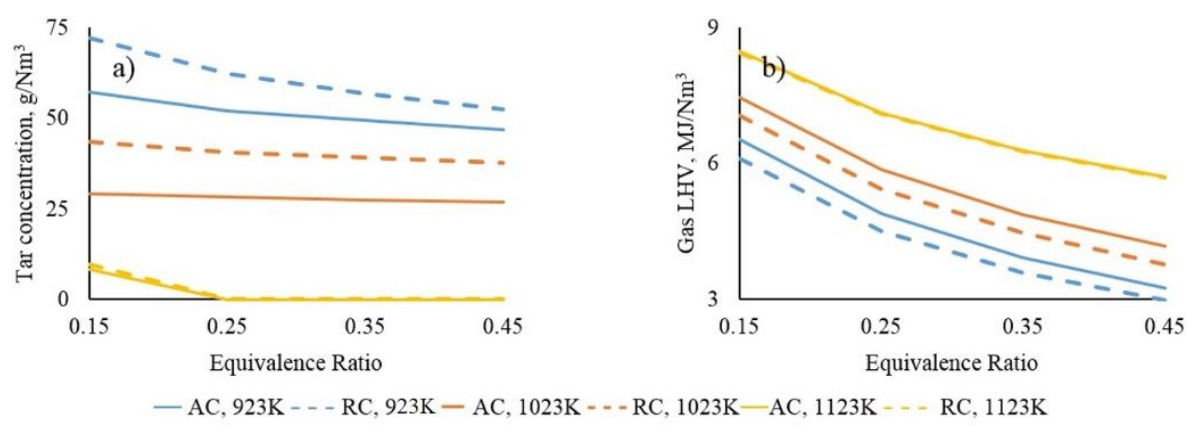

Figure 7. (a) Tar concentration $\left(\mathrm{g} / \mathrm{Nm}^{3}\right)$ and (b) Lower Heating Value $\left(\mathrm{MJ} / \mathrm{Nm}^{3}\right)$ as a function of equivalence ratio and reforming temperature at a gasification temperature of $923 \mathrm{~K}$ and reforming residence time of 0.5 seconds, using regular char and activated char as catalysts.

Simulations indicated that the tar distribution changed according to the operating temperature and equivalence ratio; for this series of simulations, the equivalence ratio and gasification and reforming temperatures were varied, while the residence time was held constant at 0.5 seconds. The distribution of tar under different conditions is depicted in Figure 8. The toluene and naphthalene were almost completely reformed using a catalyst at reforming temperatures of $1173 \mathrm{~K}$, regardless of the gasification conditions; increasing the residence time can reduce the tar contents and required temperatures even further, as explained in section 4.1.2. The most stable tar was benzene, whereas the most easily decomposed tar was toluene.

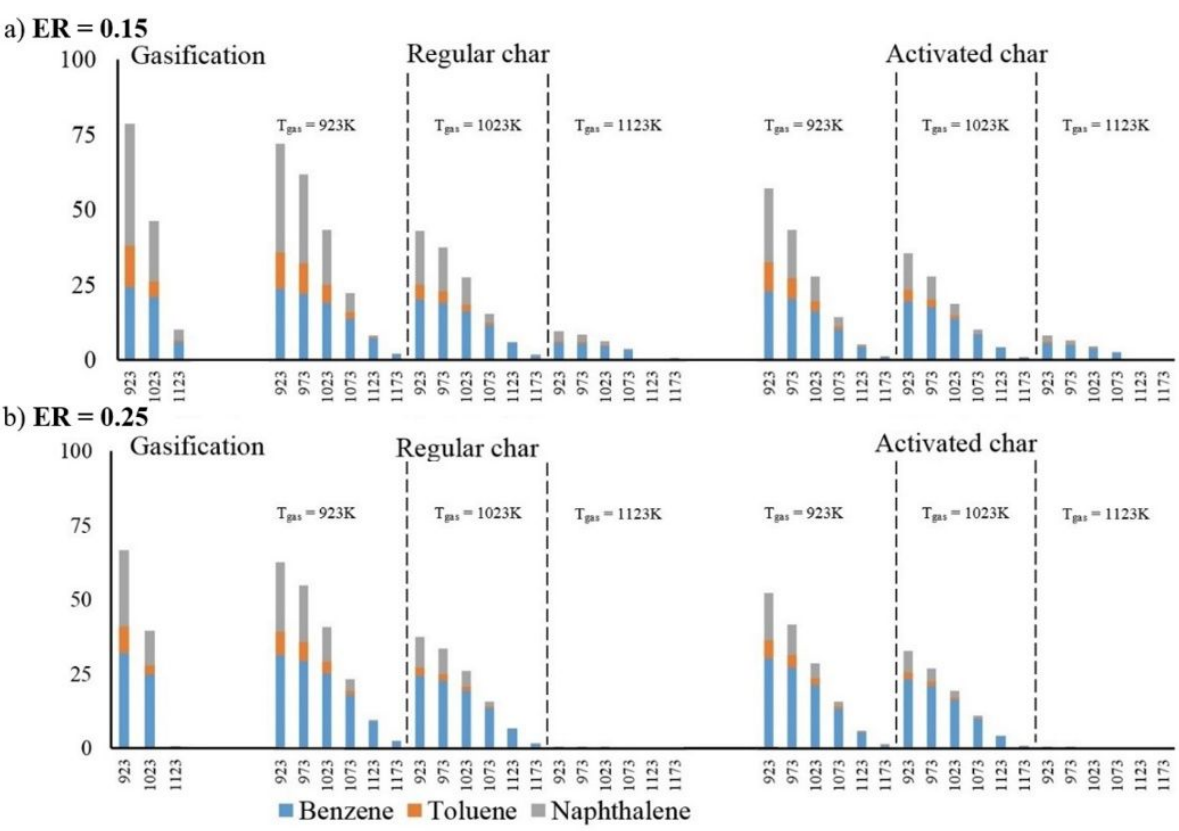

Figure 8. Tar concentration, in $\mathrm{g} / \mathrm{Nm}^{3}$ at the outlet of the gasifier, outlet of the reformer using a char catalyst and outlet of the reformer using an activated char catalyst, with a residence time of 0.5 seconds. a) $E R=0.15$ and b) $E R=0.25$. 
The tar yields can be manipulated by changing the gasification temperatures, reforming temperatures or equivalence ratios. On one hand, the tar contents in the produced gas are reduced to values less than $0.005 \mathrm{~g} / \mathrm{Nm}^{3}$ when the $\mathrm{ER}$ is 0.25 at a gasifying temperature of at least $1123 \mathrm{~K}$. On the other hand, by incorporating a reforming stage with regular or activated char at $1173 \mathrm{~K}$, after gasifying at $1023 \mathrm{~K}$, the tar yields will consist only on benzene in low concentrations (less than $1 \mathrm{~g} / \mathrm{Nm}^{3}$ ); this allows reducing the ER to 0.15 , leading to increases in the LHV of the gas and process efficiency. Gasifying at $1023 \mathrm{~K}$ and reforming at $1123 \mathrm{~K}$ results in less than $3 \mathrm{~g} / \mathrm{Nm}^{3}$ benzene as the only tar species. Although this is a relatively high tar concentration, when benzene is the only tar species, for some applications such as combustion, the produced gas might not require as intricate post-treatment, leading to some possible savings ${ }^{43}$. Moreover, alternative gas treatments such as those based on the mixture dew point may be utilized in these cases ${ }^{43-45}$. While it is clear that the incorporation of a catalyst and high temperatures are advantageous to the process in terms of syngas quality, the efficiency represent an additional pillar for process evaluation, as explained in section 4.2.

\subsubsection{Effect of the reforming temperature and residence time. Results from simulations varying the} residence time in the reforming reactor are found in Figure 9. For this group of simulations, the gasification temperature and equivalence ratio were held constant at $923 \mathrm{~K}$ and 0.25 . Figures 9a and 9b show the tar contents and LHV of the gas using regular char, while $9 \mathbf{c}$ and $9 \mathbf{d}$ show the tar contents and LHV of the gas using activated char. As expected, increasing the residence time decreased the temperature necessary to obtain complete tar conversion. This effect is most notorious at low residence times, where the temperatures required to achieve significant conversion are higher. Increasing the residence time from 0.2 to 1 second decreases the temperature necessary for complete tar conversion by about 200 degrees.
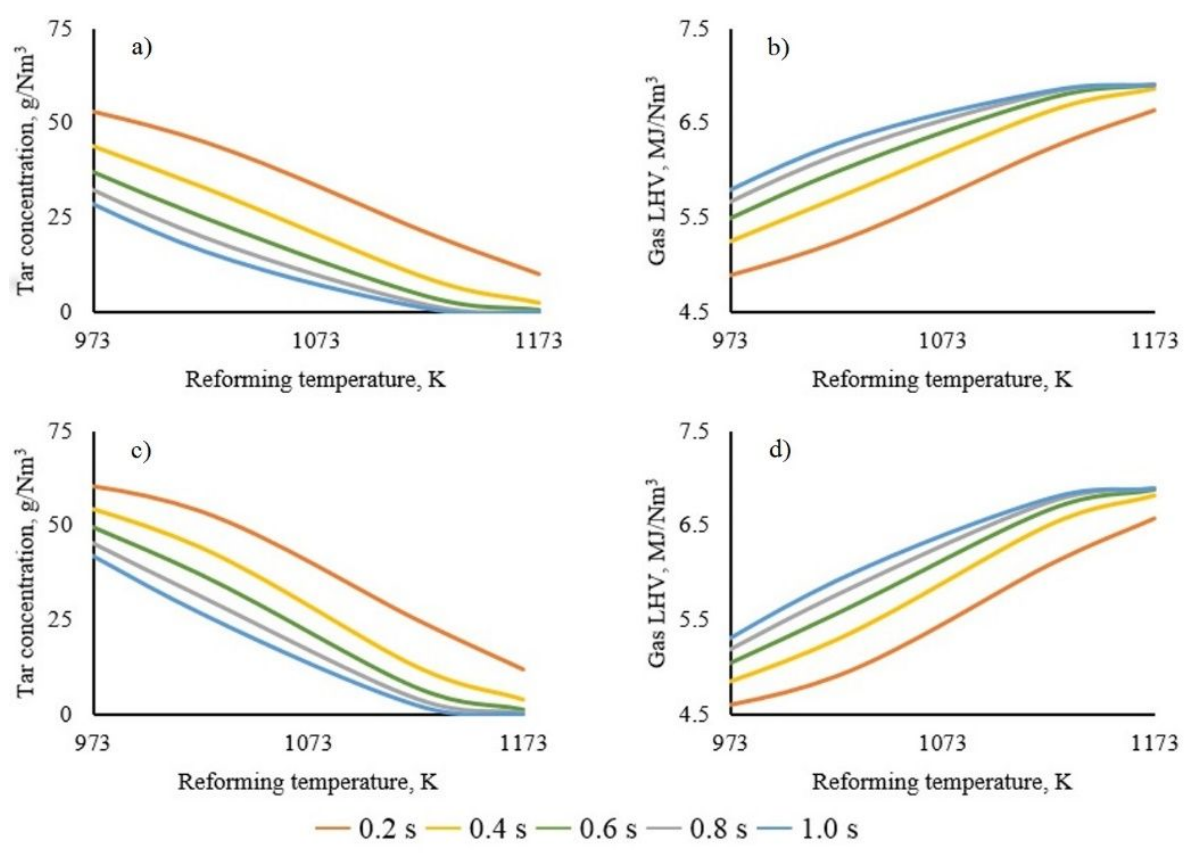
Figure 9. Effect of the residence time and reforming temperature in the tar contents and LHV of the gas. a) and b) are the tar contents and LHV, respectively, when using regular char as catalyst, while c) and d) correspond to the tar contents and LHV, respectively, using activated char catalyst. The gasification temperatures and equivalence ratios were $923 \mathrm{~K}$ and 0.25 , respectively.

4.2. Assessment of the process efficiency. The Carbon Conversion Efficiencies (CCE), gas yield, Cold Gas Efficiencies (CGE) and exergy efficiencies of the process were determined under a range of conditions. Since the CCE and gas yield only depend on the gasification stage, these are presented first in a separate subsection.

4.2.1 Carbon conversion efficiency and gas yield. Figure $\mathbf{1 0}$ presents the effect of the gasification operation conditions (temperature and equivalence ratio) in the gas yield and carbon conversion efficiency. Because higher ER means more oxygen available for oxidation reactions (and increased CO and $\mathrm{CO}_{2}$ production), increasing the ER increases the gas yield and carbon conversion efficiency. Although it might appear that a high ER is beneficial, high low-quality gas yields are undesirable and costly ${ }^{46}$.

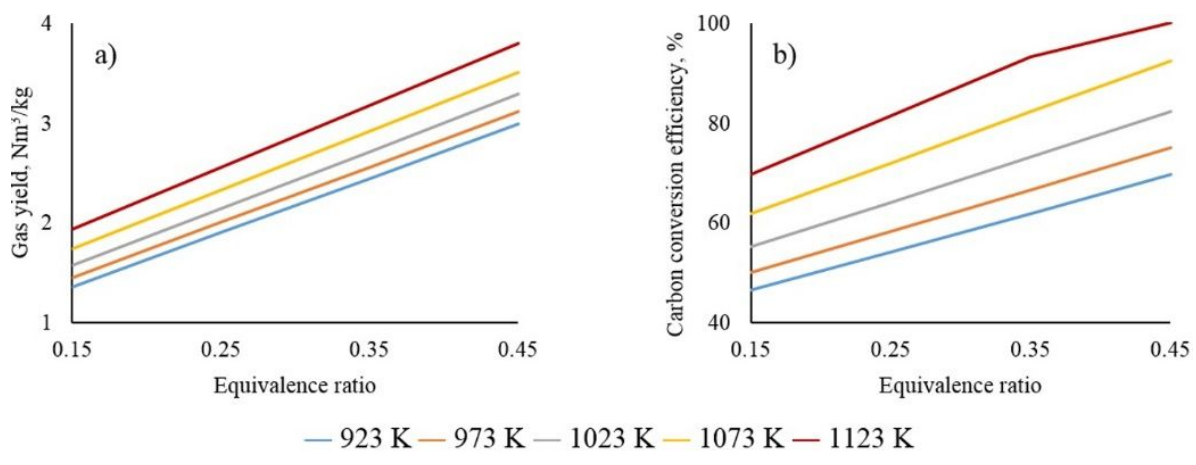

Figure 10. a) Gas yield and b) Carbon Conversion Efficiency (CCE) provided by the gasifier as a function of temperature and equivalence ratio.

4.2.2. First and second law analysis. Figure 11a displays how temperature and equivalence ratio affect the CGE of the process. The CGE decreases slightly with ER and increases with gasification temperature, because even if the gas has a lower LHV, the gas yield increases, leading to more energy produced per kg biomass; nevertheless, the production of a large amount of low-quality gas is not desirable.

Apart from calculating the CGE, an exergy analysis of the two stages under different gasification and reforming temperatures and equivalence ratios was conducted. Results are found in Figure 11b and 11c, where the gasification and reforming exergy efficiencies, respectively, are shown. The gasification exergy efficiency increased with temperature and decreased with ER, while the reforming exergy efficiency increased significantly with reforming temperature, slightly with equivalence ratio, and decreased with increasing gasification temperature. 

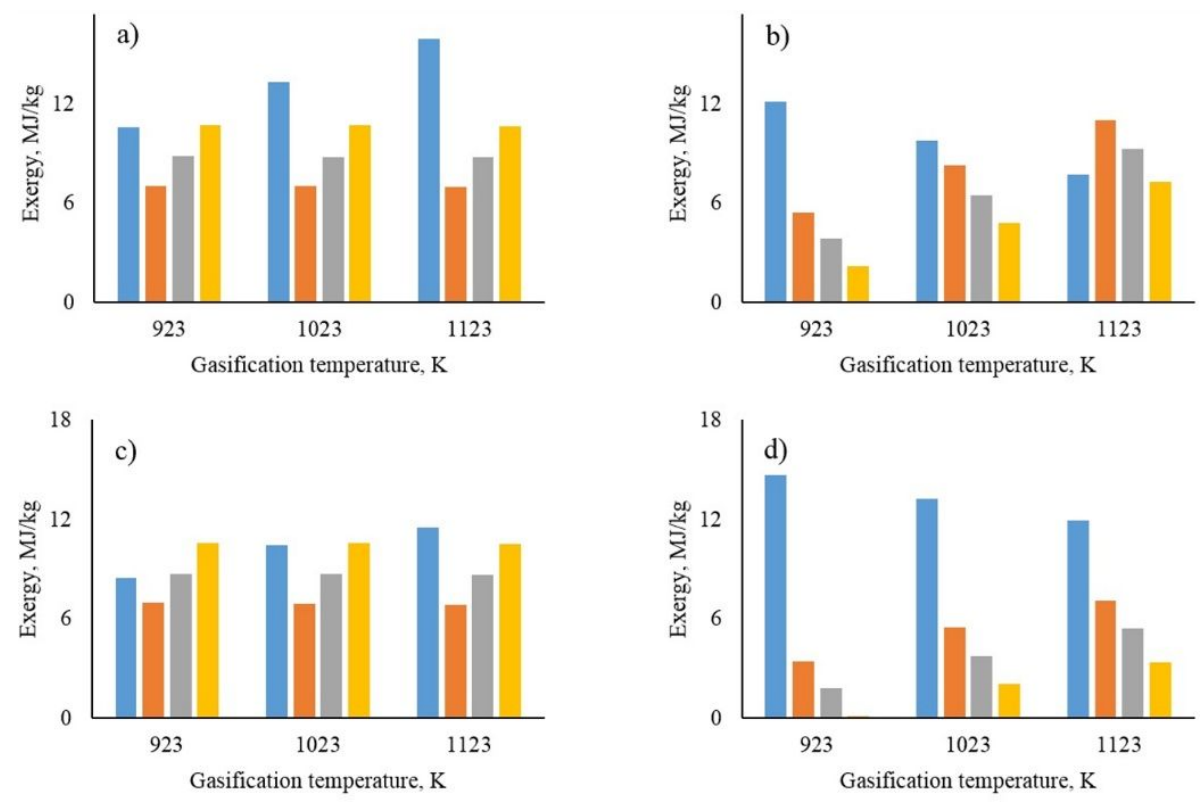

" Gasification " Reforming at $923 \mathrm{~K}$ " Reforming at $1023 \mathrm{~K}$ " Reforming at $1123 \mathrm{~K}$

Figure 12. Total ( $a$ and $c$ ) and destroyed ( $b$ and d) exergies calculated at the outlet of the gasifier and the reformer at different temperatures. The equivalence ratios are 0.15 for $\mathrm{a}$ and $\mathrm{b}$ and 0.45 for $\mathrm{c}$ and $\mathrm{d}$. 
4.3. Effective operation conditions. As presented in sections 4.1 and 4.2, the activated char was the best catalyst; for that reason the results shown in this section are with that catalyst only. The criteria employed to determine operation parameters in the reactor was: (1) maximize the cold gas efficiency, (2) maximize the process efficiency and (3) produce the syngas with the highest LHV.

Figure 13 shows the effect of gasification temperature and ER in the process CCE and CGE. The CCE increased with temperature and ER while the CGE only increased marginally with ER. The CCE and CGE in air-blown gasifiers normally varies between 60 and $90 \%$, and 60 and $80 \%$, respectively ${ }^{10}$. By this criteria, high equivalence ratios and gasification temperatures are desirable. However, increasing the ER decreased the LHV of the produced gas. Moreover, as described in section 4.1, the use of char catalysts increased the gas LHV while decreasing its tar contents, thus the ER becomes relevant for the CCE only. Figures 14a, $\mathbf{b}, \mathbf{c}$ and $\mathbf{d}$ show the gas LHV and tar contents as a function of gasification and reforming temperatures at an equivalence ratio of $0.15,0.25,0.35$ and 0.45 , respectively. At the same time, from the second law analysis, the gas exergy after reforming was unaffected by the gasification conditions, hence, the process thermodynamically benefits from low gasification and high reforming temperatures.

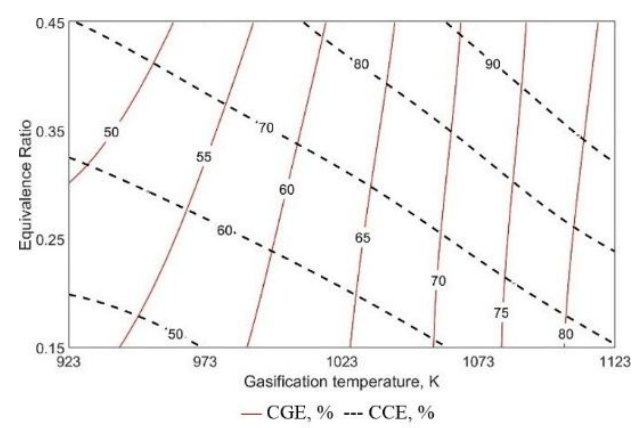

Figure 13. Effect of the gasification temperature and equivalence ratio in the CGE and CCE.
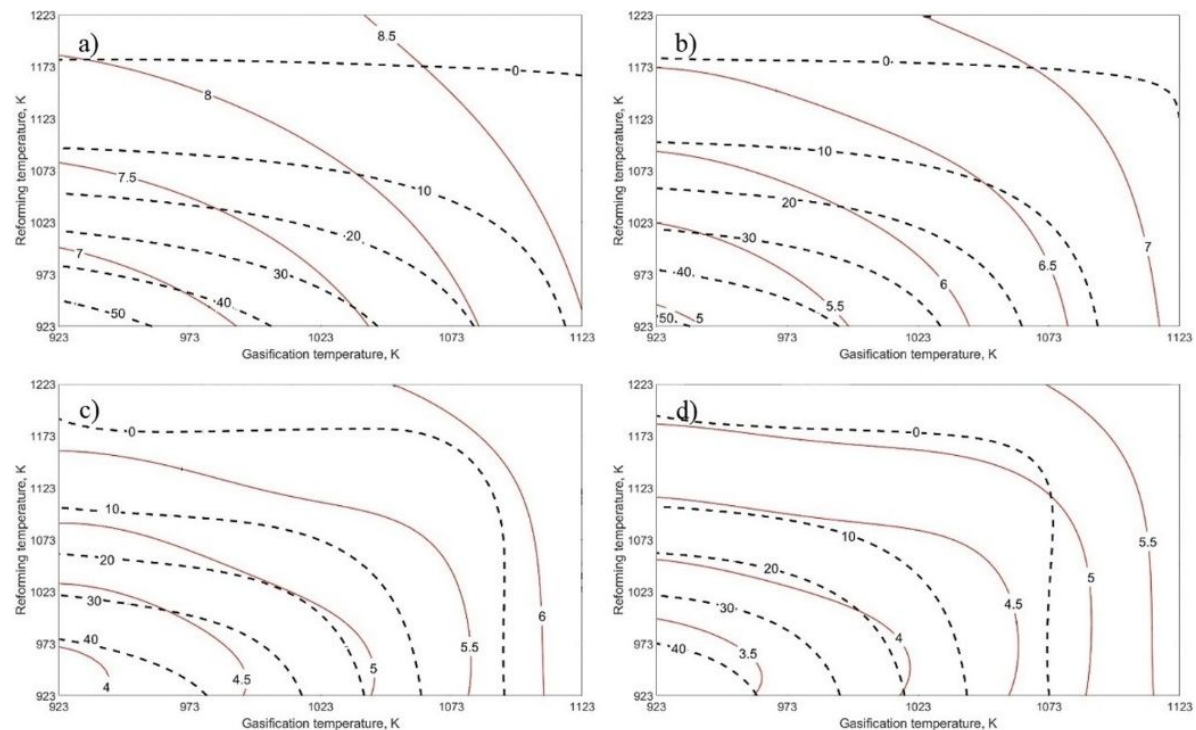

LHV, MJ/Nm ${ }^{3}$-.- Tar contents, $\mathrm{g} / \mathrm{Nm}^{3}$

Figure 14. Effect of the gasification and reforming temperatures in LHV of the syngas and the tar contents, when gasifying at an equivalence ratio of a) 0.15 and b) 0.25 . 
Simulations indicate that, under the conditions studied in this work, a gasification temperature of $1023 \mathrm{~K}$, an equivalence ratio of 0.15 and a reforming temperature high enough to reform the tar $(1173 \mathrm{~K}$ at a residence time of 0.5 seconds) leads to producing a virtually tar-free gas with a LHV of more than $8 \mathrm{MJ} / \mathrm{Nm}^{3}$. Figure 15 shows the Sankey diagram representing the exergy flows under these operation conditions. A large amount of exergy is destroyed during gasification, due to differences in temperature and changes in the species composition. Contrarily, during reforming, the exergy loses are more significant than the exergy destruction. Some of the heat in the syngas could be used to dry the biomass and increase the process efficiency, as more than the $2.26 \mathrm{MJ} / \mathrm{kg}$ necessary to vaporize the water in the biomass is available for recovery ${ }^{47}$. On the other hand, the exergy destroyed during gasification remains an engineering challenge. Technologies such as supercritical gasification aim to tackle losses in efficiency but still require further research; an overview of these technologies is outside of the scope of this work $^{48}$.

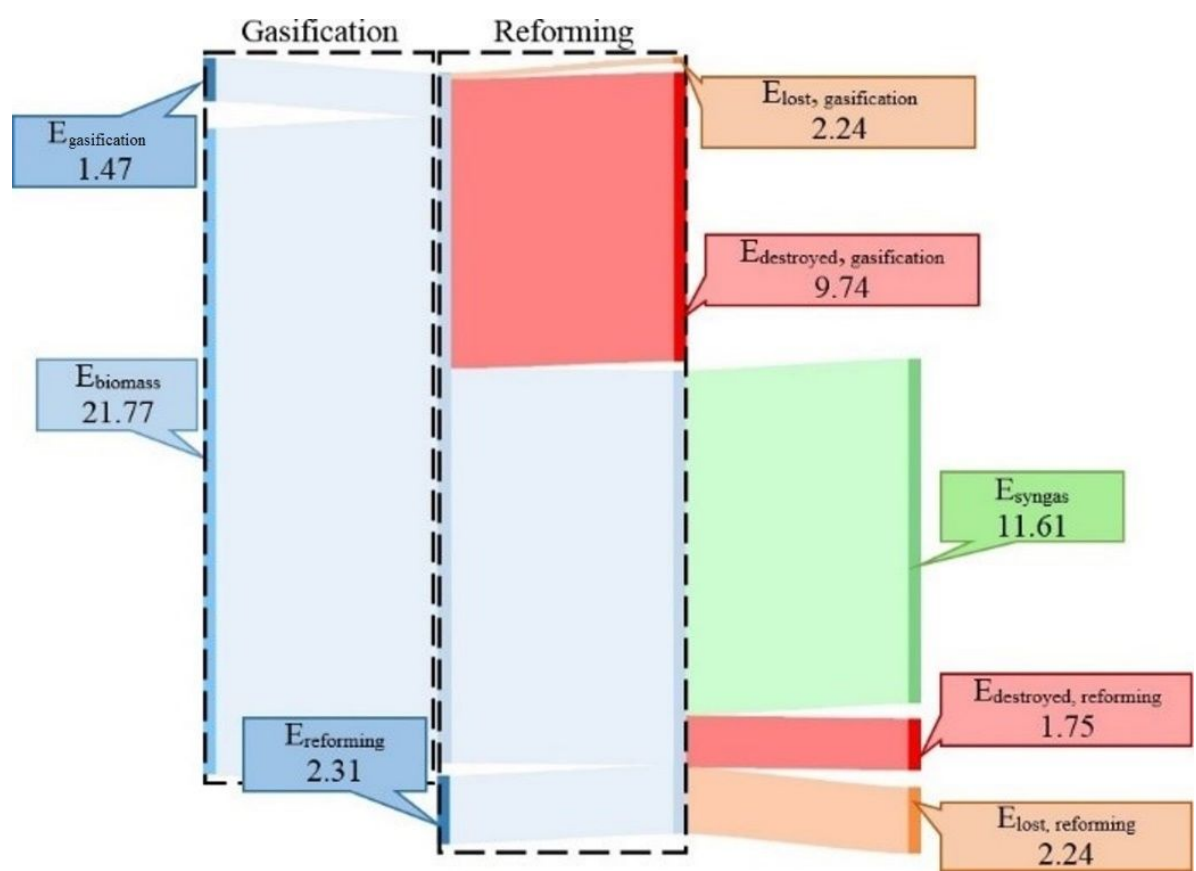

Figure 15. Sankey diagram for the exergy flows at $T_{\text {gas }}=1073 \mathrm{~K}, \mathrm{~T}_{\text {ref }}=1173 \mathrm{~K}$ and $\mathrm{ER}=0.15$. All the exergies are in $\mathrm{MJ} / \mathrm{kg}$. $\mathrm{E}_{\text {lost }}$ and $\mathrm{E}_{\text {destroyed }}$ are the exergies lost to the surroundings and destroyed either during gasification or reforming. $\mathrm{E}_{\text {gasification }}$ are the exergy contents of the air supplied for gasification and the exergy added from external heat, $\mathrm{E}_{\text {biomass }}$ are the exergy contents of the studied biomass, $\mathrm{E}_{\text {reforming }}$ are the exergy contents of the reforming agents plus the externally added heat for reforming. $\mathrm{E}_{\text {syngas }}$ is the exergy of the syngas downstream of the reactor.

\section{Summary and conclusions}

A model to simulate a two-stage reactor for gasification and tar clean-up was developed and validated. Simulations were conducted to analyze the effect of operation parameters in the performance of the reactor and gas quality: incorporation of a catalyst, gasification temperature, equivalence ratio, reforming temperature and reforming residence time. Further, a second law analysis was conducted to determine the maximum obtainable work from the proposed system. The following was concluded: 
- High temperatures, either during gasification or reforming, are beneficial for the syngas quality. According to results, the process gasification temperature should aim to provide a high carbon conversion efficiency and the reforming temperature should be adjusted to eradicate the tar.

- When reforming tar using char catalysts, the required residence times for significant conversion at temperatures less than $1173 \mathrm{~K}$ are at least 0.3 seconds.

- Depending on the end use of the product gas, the extent of tar clean up can be adjusted to optimize the spent resources. For example, since benzene is not a tar as problematic as polyaromatic hydrocarbons (i.e. it does not condense at high temperatures), it can be combusted along with the produced gas for energy.

- In a two-stage reactor for gasification and tar reforming, the gasification process is an important source of irreversibilities. On the other hand, a large amount of exergy is lost during reforming. Although the loses cannot be completely avoided, the efficiency of the process can be improved with the incorporation of heat recovery or heat from sustainable sources.

The findings indicate the relevance of employing char catalysts during staged gasification, demonstrated by the increases in thermodynamic efficiency and should prove useful for scientists and engineers working in improving biomass gasification. Moreover, biomass residual char is shown as a competent catalyst to upgrade the gas produced during gasification. This represents a step forward in improving the sustainability of biomass gasification.

\section{Acknowledgements}

The author would like to thank the Consejo Nacional de Ciencia y Tecnología (CONACYT), grant number 440077 , for the financial support provided for this research.

\section{Declaration of interest}

None.

\section{References}

(1) Abdoulmoumine, N.; Adhikari, S.; Kulkarni, A.; Chattanathan, S. A Review on Biomass Gasification Syngas Cleanup. Appl. Energy 2015, 155, 294-307. https://doi.org/10.1016/j.apenergy.2015.05.095.

(2) Asadullah, M. Barriers of Commercial Power Generation Using Biomass Gasification Gas: A Review. Renew. Sustain. Energy Rev. 2014, 29, 201-215. https://doi.org/10.1016/j.rser.2013.08.074.

(3) Zhang, X. Essential Scientific Mapping of the Value Chain of Thermochemically Converted SecondGeneration Bio-Fuels. Green Chem. 2016, 18 (19), 5086-5117. https://doi.org/10.1039/C6GC02335E.

(4) Arpornwichanop, A.; Nakyai, T.; Patcharavorachot, Y.; Authayanun, S.; Saebea, D.; Assabumrungrat, S. Exergoeconomics of Hydrogen Production from Biomass Air-Steam Gasification with Methane CoFeeding. Energy Convers. Manag. 2017, 140, 228-239. https://doi.org/10.1016/j.enconman.2017.03.002.

(5) Gómez-Barea, A.; Ollero, P.; Leckner, B. Optimization of Char and Tar Conversion in Fluidized Bed Biomass Gasifiers. Fuel 2013, 103, 42-52. https://doi.org/10.1016/j.fuel.2011.04.042.

(6) Devi, L.; Ptasinski, K. J.; Janssen, F. J. J. G. A Review of the Primary Measures for Tar Elimination in Biomass Gasification Processes. Biomass and Bioenergy 2002, 24 (2), 125-140. https://doi.org/10.1016/S0961-9534(02)00102-2. 
De Lasa, H.; Salaices, E.; Mazumder, J.; Lucky, R. Catalytic Steam Gasification of Biomass: Catalysts, Thermodynamics and Kinetics. Chem. Rev. 2011, 111 (9), 5404-5433.

https://doi.org/10.1021/cr200024w.

(8) Lu, P.; Huang, Q.; Bourtsalas, A. C.; Chi, Y.; Yan, J. Effect of Operating Conditions on the Coke Formation and Nickel Catalyst Performance During Cracking of Tar. Waste and Biomass Valorization 2017, No. 0123456789. https://doi.org/10.1007/s12649-017-0044-5.

(9) Guan, G.; Kaewpanha, M.; Hao, X.; Abudula, A. Catalytic Steam Reforming of Biomass Tar: Prospects and Challenges. Renew. Sustain. Energy Rev. 2016, 58, 450-461. https://doi.org/10.1016/j.rser.2015.12.316.

(10) Brown, R. C. Thermochemical Processing of Biomass: Conversion into Fuels, Chemicals and Power; 2011. https://doi.org/10.1002/9781119990840.

(11) Buentello-Montoya, D. A.; Zhang, X.; Li, J. The Use of Gasification Solid Products as Catalysts for Tar Reforming. Renew. Sustain. Energy Rev. 2019, 107 (December 2018), 399-412. https://doi.org/10.1016/j.rser.2019.03.021.

(12) Abu El-Rub, Z.; Bramer, E. A.; Brem, G. Experimental Comparison of Biomass Chars with Other Catalysts for Tar Reduction. Fuel 2008, 87 (10-11), 2243-2252.

https://doi.org/10.1016/j.fuel.2008.01.004.

(13) Fuentes-cano, D.; Gómez-barea, A.; Nilsson, S.; Ollero, P. Decomposition Kinetics of Model Tar Compounds over Chars with Different Internal Structure to Model Hot Tar Removal in Biomass Gasification. 2013, 228, 1223-1233. https://doi.org/10.1016/j.cej.2013.03.130.

(14) Hervy, M.; Villot, A.; Gérente, C.; Pham, D.; Weiss-hortala, E.; Nzihou, A.; Le, L. Catalytic Cracking of Ethylbenzene as Tar Surrogate Using Pyrolysis Chars from Wastes. Biomass and Bioenergy 2018, 117 (January), 86-95. https://doi.org/10.1016/j.biombioe.2018.07.020.

(15) Zainal, Z.A;Ali, R;Lean, C. . Prediction of Performance of a Downdraft Modeling for Different Biomass Materials. Energy Convers. Manag. 2001, 42 (42), 1499-1515.

(16) Lim, Y. Il; Lee, U. Do. Quasi-Equilibrium Thermodynamic Model with Empirical Equations for AirSteam Biomass Gasification in Fluidized-Beds. Fuel Process. Technol. 2014, 128, 199-210. https://doi.org/10.1016/j.fuproc.2014.07.017.

(17) Schuster, G.; Löffler, G.; Weigl, K.; Hofbauer, H. Biomass Steam Gasification - An Extensive Parametric Modeling Study. Bioresour. Technol. 2001, 77 (1), 71-79. https://doi.org/10.1016/S09608524(00)00115-2.

(18) Barman, N. S.; Ghosh, S.; De, S. Gasification of Biomass in a Fixed Bed Downdraft Gasifier - A Realistic Model Including Tar. Bioresour. Technol. 2012, 107, 505-511. https://doi.org/10.1016/j.biortech.2011.12.124.

(19) Aydin, E. S.; Yucel, O.; Sadikoglu, H. Development of a Semi-Empirical Equilibrium Model for Downdraft Gasification Systems. Energy 2017, 130, 86-98. https://doi.org/10.1016/j.energy.2017.04.132.

(20) Font Palma, C. Modelling of Tar Formation and Evolution for Biomass Gasification: A Review. Appl. Energy 2013, 111, 129-141. https://doi.org/10.1016/j.apenergy.2013.04.082.

(21) Tuomi, S.; Kurkela, E.; Simell, P.; Reinikainen, M. Behaviour of Tars on the Filter in High Temperature Filtration of Biomass-Based Gasification Gas. Fuel 2015, 139, 220-231. https://doi.org/10.1016/j.fuel.2014.08.051.

(22) Brunner, P. H.; Rechberger, H. Waste to Energy - Key Element for Sustainable Waste Management. Waste Manag. 2015, 37, 3-12. https://doi.org/10.1016/j.wasman.2014.02.003.

(23) Goodwin, D. G.; Moffat, H. K.; Speth, R. L. Cantera: An Object-Oriented Software Toolkit for Chemical Kinetics, Thermodynamics, and Transport Processes. http://www.cantera.org 2017. https://doi.org/10.5281/zenodo.170284.

(24) Privat, R.; Jaubert, J. N.; Berger, E.; Coniglio, L.; Lemaitre, C.; Meimaroglou, D.; Warth, V. Teaching the Concept of Gibbs Energy Minimization through Its Application to Phase-Equilibrium Calculation. $J$. Chem. Educ. 2016, 93 (9), 1569-1577. https://doi.org/10.1021/acs.jchemed.6b00205.

(25) Kaushal, P.; Tyagi, R. Advanced Simulation of Biomass Gasification in a Fluidized Bed Reactor Using ASPEN PLUS. Renew. Energy 2017, 101, 629-636. https://doi.org/10.1016/j.renene.2016.09.011.

(26) Chase, M. NIST-JANAF Thermochemical Tables, 4th Edition. Journal of Physical and Chemical Reference Data, Monograph 9. 1998, p 1952. https://doi.org/citeulike-article-id:12140840.

(27) Smith, J. M. Introduction to Chemical Engineering Thermodynamics. J. Chem. Educ. 1950. https://doi.org/10.1021/ed027p584.3.

(28) Petersen, I.; Werther, J. Experimental Investigation and Modeling of Gasification of Sewage Sludge in the Circulating Fluidized Bed. Chem. Eng. Process. Process Intensif. 2005, 44 (7), 717-736. https://doi.org/10.1016/j.cep.2004.09.001.

(29) Su, Y.; Luo, Y.; Chen, Y.; Wu, W.; Zhang, Y. Experimental and Numerical Investigation of Tar 
Destruction under Partial Oxidation Environment. Fuel Process. Technol. 2011, 92 (8), 1513-1524. https://doi.org/10.1016/j.fuproc.2011.03.013.

(30) Jess, A. Mechanisms and Kinetics of Thermal Reactions of Aromatics From Pyrolysis of Solid Fuels. Fuel 1996, 75 (12), 1441-1448.

(31) Buentello-Montoya, D.; Zhang, X.; Marques, S.; Geron, M. Investigation of Competitive Tar Reforming Using Activated Char as a Catalyst. Energy Procedia 2019.

(32) Pellegrini, L. F.; de Oliveira, S. Exergy Analysis of Sugarcane Bagasse Gasification. Energy 2007. https://doi.org/10.1016/j.energy.2006.07.028.

(33) Font Palma, C. Model for Biomass Gasification Including Tar Formation and Evolution. Energy \& Fuels 2013, 27, 2693-2702. https://doi.org/dx.doi.org/10.1021/ef4004297.

(34) Anis, S.; Zainal, Z. A. Tar Reduction in Biomass Producer Gas via Mechanical, Catalytic and Thermal Methods: A Review. Renew. Sustain. Energy Rev. 2011, 15 (5), 2355-2377. https://doi.org/10.1016/j.rser.2011.02.018.

(35) Jayah, T. H.; Aye, L.; Fuller, R. J.; Stewart, D. F. Computer Simulation of a Downdraft Wood Gasifier for Tea Drying. Biomass and Bioenergy 2003, 25 (4), 459-469. https://doi.org/10.1016/S09619534(03)00037-0.

(36) Kramb, J.; Konttinen, J.; Gómez-barea, A.; Moilanen, A.; Umeki, K. Modeling Biomass Char Gasification Kinetics for Improving Prediction of Carbon Conversion in a Fluidized Bed Gasifier. FUEL 2014, 132, 107-115. https://doi.org/10.1016/j.fuel.2014.04.014.

(37) Tuomi, S.; Kaisalo, N.; Simell, P.; Kurkela, E. Effect of Pressure on Tar Decomposition Activity of Different Bed Materials in Biomass Gasification Conditions. Fuel 2015, 158, 293-305. https://doi.org/10.1016/j.fuel.2015.05.051.

(38) Eri, Q.; Wu, W.; Zhao, X. Numerical Investigation of the Air-Steam Biomass Gasification Process Based on Thermodynamic Equilibrium Model. Energies 2017, 10 (12). https://doi.org/10.3390/en10122163.

(39) Obernberger, I.; Biedermann, F.; Widmann, W.; Riedl, R. Concentrations of Inorganic Elements in Biomass Fuels and Recovery in the Different Ash Fractions. Biomass and Bioenergy 1997, 12 (3), 211 224. https://doi.org/10.1016/S0961-9534(96)00051-7.

(40) Kinoshita, C. M.; Wang, Y.; Zhou, Z. Tar Formation under Different Biomass Gasification Conditions. Fuel Energy Abstr. 1995, 36 (1), 33. https://doi.org/10.1016/0140-6701(95)95820-7.

(41) Świerczyński, D.; Libs, S.; Courson, C.; Kiennemann, A. Steam Reforming of Tar from a Biomass Gasification Process over Ni/Olivine Catalyst Using Toluene as a Model Compound. Appl. Catal. B Environ. 2007, 74 (3-4), 211-222. https://doi.org/10.1016/j.apcatb.2007.01.017.

(42) Phuphuakrat, T.; Namioka, T.; Yoshikawa, K. Tar Removal from Biomass Pyrolysis Gas in Two-Step Function of Decomposition and Adsorption. Appl. Energy 2010, 87 (7), 2203-2211. https://doi.org/10.1016/j.apenergy.2009.12.002.

(43) Boerrigter, H.; van Paasen, S. V. B.; Bergman, P. C. a; Könemann, J. W.; Emmen, R.; Wijnands, a. "Olga” Tar Removal Technology; 2005.

(44) Kiel, J.; Paasen, S. Van; Neeft, J. Primary Measures to Reduce Tar Formation in Fluidised-Bed Biomass Gasifiers. Ecn, Ecn-C-04-014 2004, No. March.

(45) Coll, R.; Salvadó, J.; Farriol, X.; Montané, D. Steam Reforming Model Compounds of Biomass Gasification Tars: Conversion at Different Operating Conditions and Tendency towards Coke Formation. Fuel Process. Technol. 2001, 74 (1), 19-31. https://doi.org/10.1016/S0378-3820(01)002144.

(46) Stevens, D. J. Hot Gas Conditioning: Recent Progress with Larger-Scale Biomass Gasification Systems. Natinal Renew. energy Lab. 2001, No. NREL/SR-510-29952, 103. https://doi.org/10.2172/786288.

(47) Basu, P. Biomass Gasification, Pyrolysis and Torrefaction. Biomass Gasification, Pyrolysis and Torrefaction 2013, 439-455. https://doi.org/10.1016/B978-0-12-396488-5.00013-7.

(48) Sikarwar, V. S.; Zhao, M.; Clough, P.; Yao, J.; Zhong, X.; Memon, M. Z.; Shah, N.; Anthony, E. J.; Fennell, P. S. An Overview of Advances in Biomass Gasification. Energy Environ. Sci. 2016, 9 (10), 2939-2977. https://doi.org/10.1039/c6ee00935b.

\section{For Table of Contents Only}




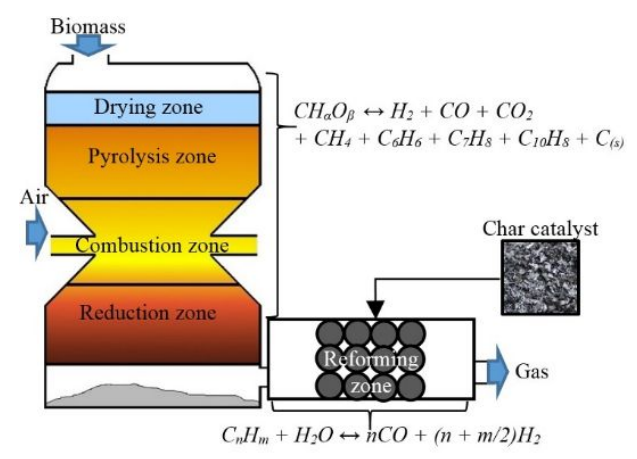



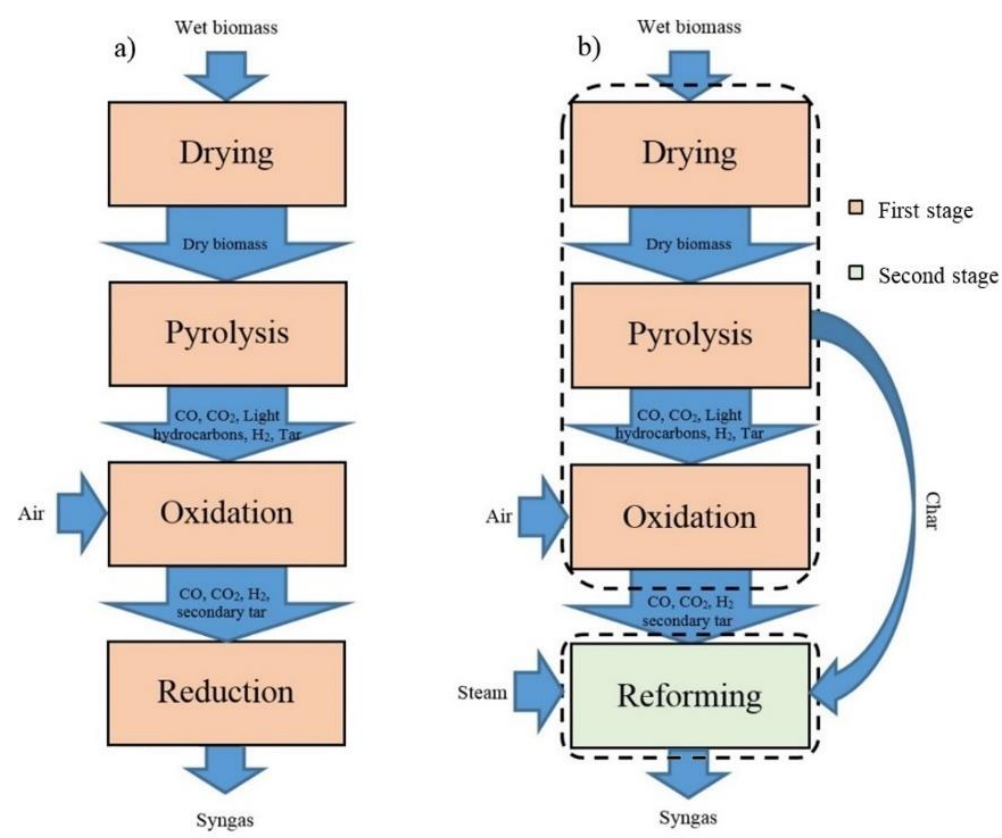
a)

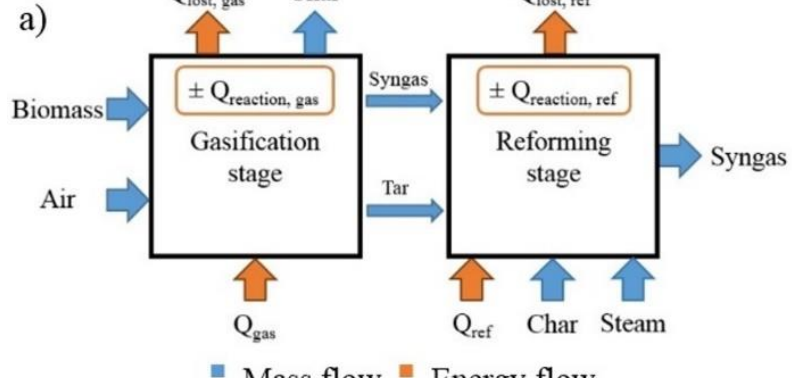

" Mass flow " Energy flow

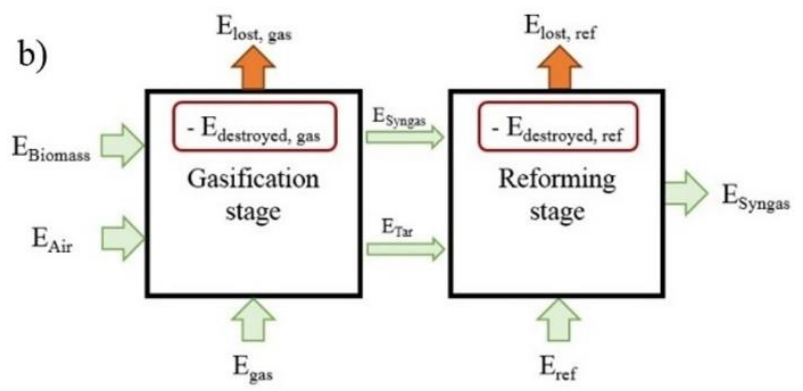

" Exergy flow " Lost exergy " Exergy destroyed 


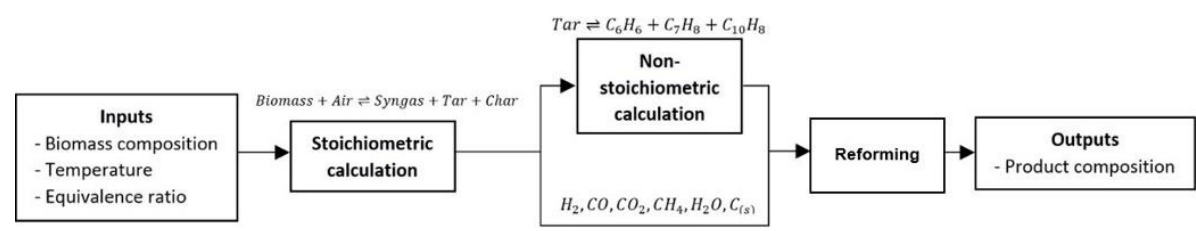

Figure 3. Flowchart of the methodology followed for the simulations. 

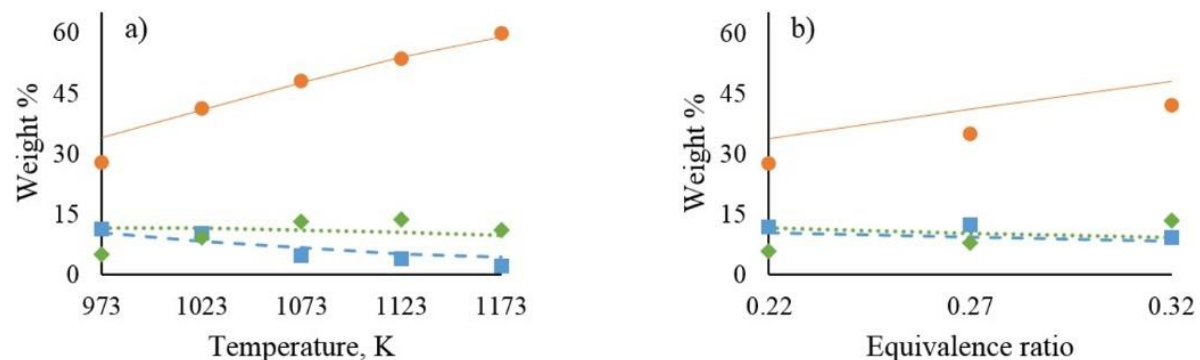

- Benzene, Kinoshita et al. $=$ Toluene, Kinoshita et al. $\$$ Naphthalene, Kinoshita et al.

Benzene, simulation - - - Toluene, simulation ..... Naphthalene, simulation

Figure 4. Comparison between simulations and experiments reported by Kinoshita et al. [11]. Tar distribution as a function of temperature (a), and equivalence ratio (b). 

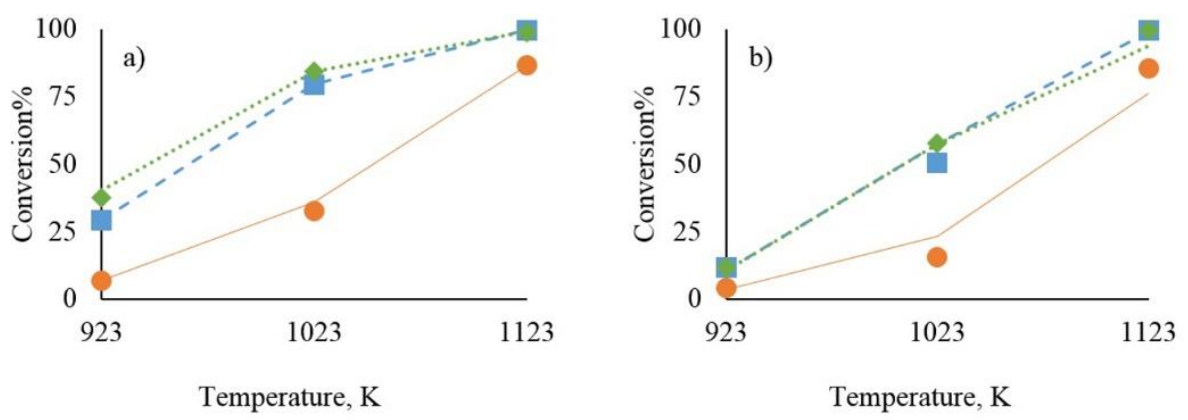

- Benzene, experiment $=$ Toluene, experiment $\bullet$ Naphthalene, experiment

Benzene, simulation - - Toluene, simulation ...... Naphthalene, simulation

Figure 5. Conversion results from computational simulations. Comparison of experimental and simulation results using a) activated and b) regular char. 

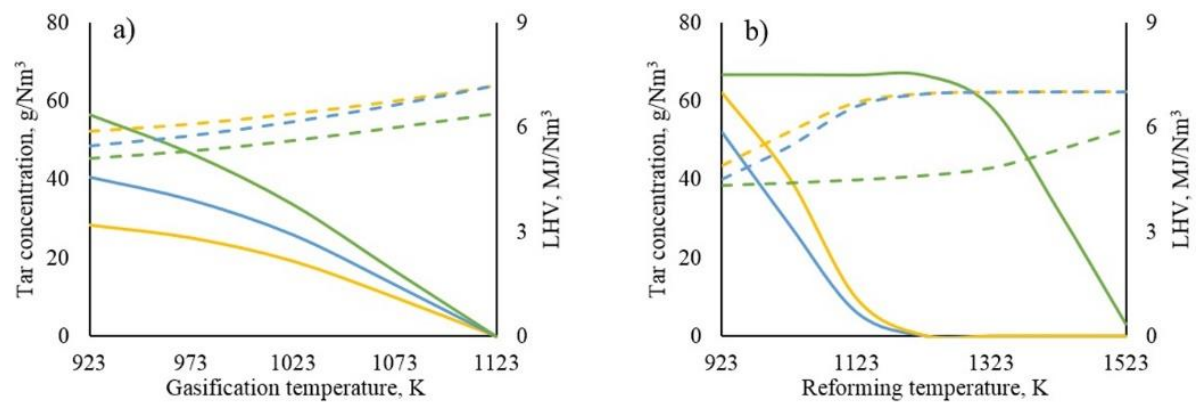

- Tar, RC — Tar, AC - Tar, No catalyst - - - LHV, RC - - LHV, AC - - - LHV, No catalyst

Figure 6. Tar concentration $\left(\mathrm{g} / \mathrm{Nm}^{3}\right)$ and Lower Heating Value $\left(\mathrm{MJ} / \mathrm{Nm}^{3}\right)$ and as a function of temperature (a) gasification temperature during reforming at $1023 \mathrm{~K}$ and (b) reforming temperature during gasification at $923 \mathrm{~K}$. For both cases the residence time and equivalence ratios were 0.5 seconds and 0.25 , respectively. 

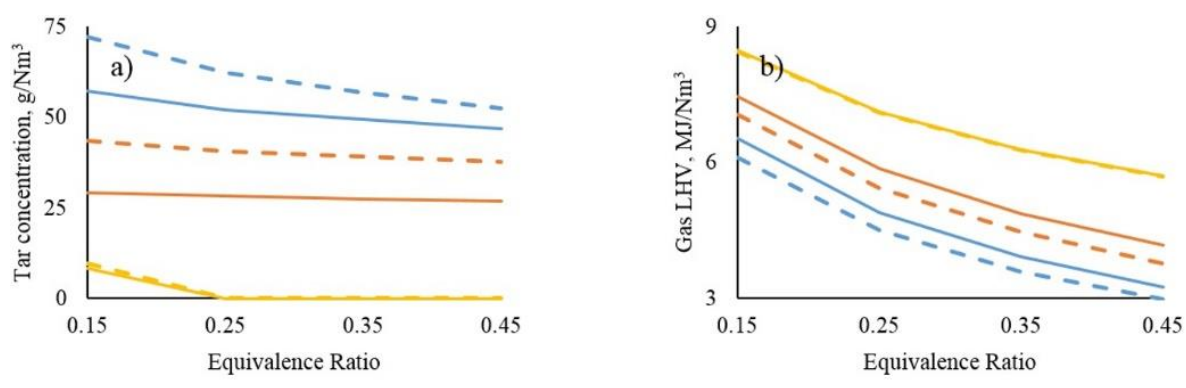

- AC, $923 \mathrm{~K}-\cdots \mathrm{RC}, 9 \mathrm{~K}$ - AC, $1023 \mathrm{~K}-\cdots \mathrm{RC}, 1023 \mathrm{~K}-\mathrm{AC}, 1123 \mathrm{~K}-\cdots \mathrm{RC}, 1123 \mathrm{~K}$

Figure 7. (a) Tar concentration $\left(\mathrm{g} / \mathrm{Nm}^{3}\right)$ and (b) Lower Heating Value $\left(\mathrm{MJ} / \mathrm{Nm}^{3}\right)$ as a function of equivalence ratio and reforming temperature at a gasification temperature of $923 \mathrm{~K}$ and reforming residence time of 0.5 seconds, using regular char and activated char as catalysts. 


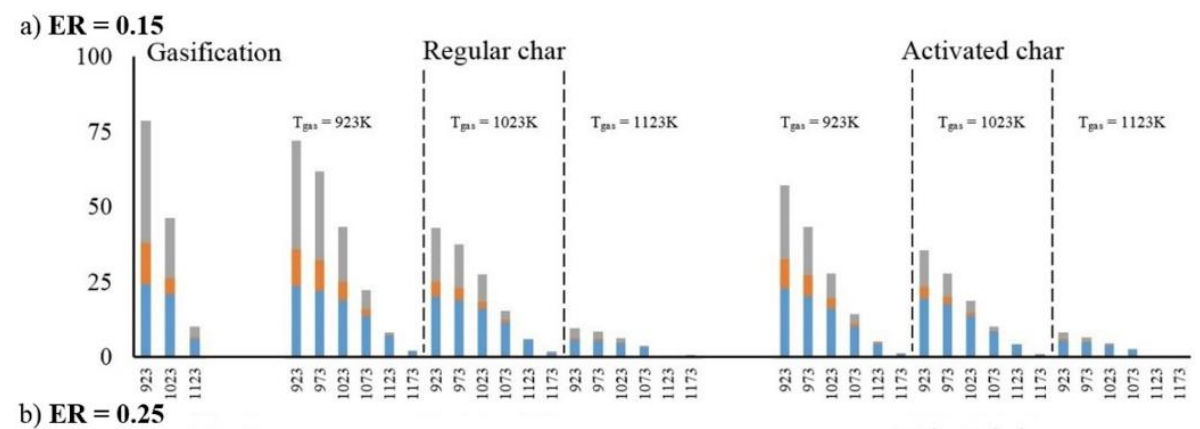

b) $\mathbf{E R}=0.25$

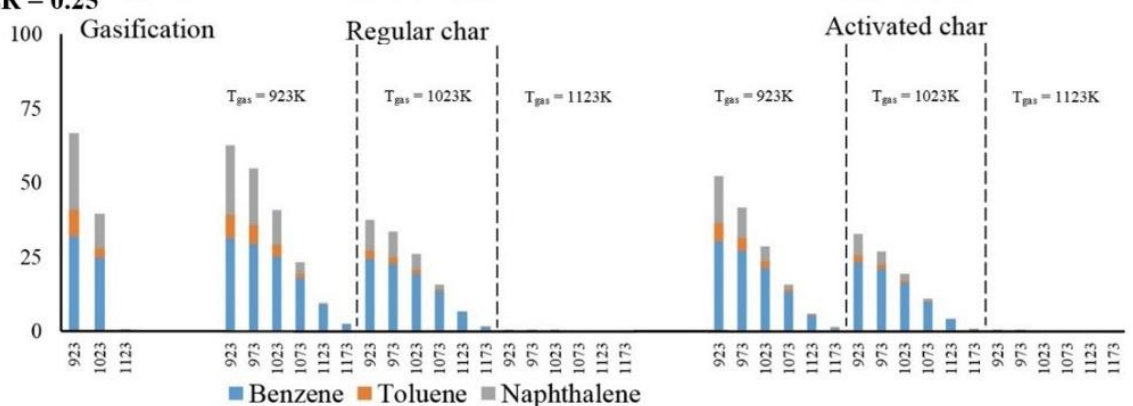

Figure 8. Tar concentration, in $\mathrm{g} / \mathrm{Nm}^{3}$ at the outlet of the gasifier, outlet of the reformer using a char catalyst and outlet of the reformer using an activated char catalyst, with a residence time of 0.5 seconds. a) $E R=0.15$ and $b) E R=0.25$. 

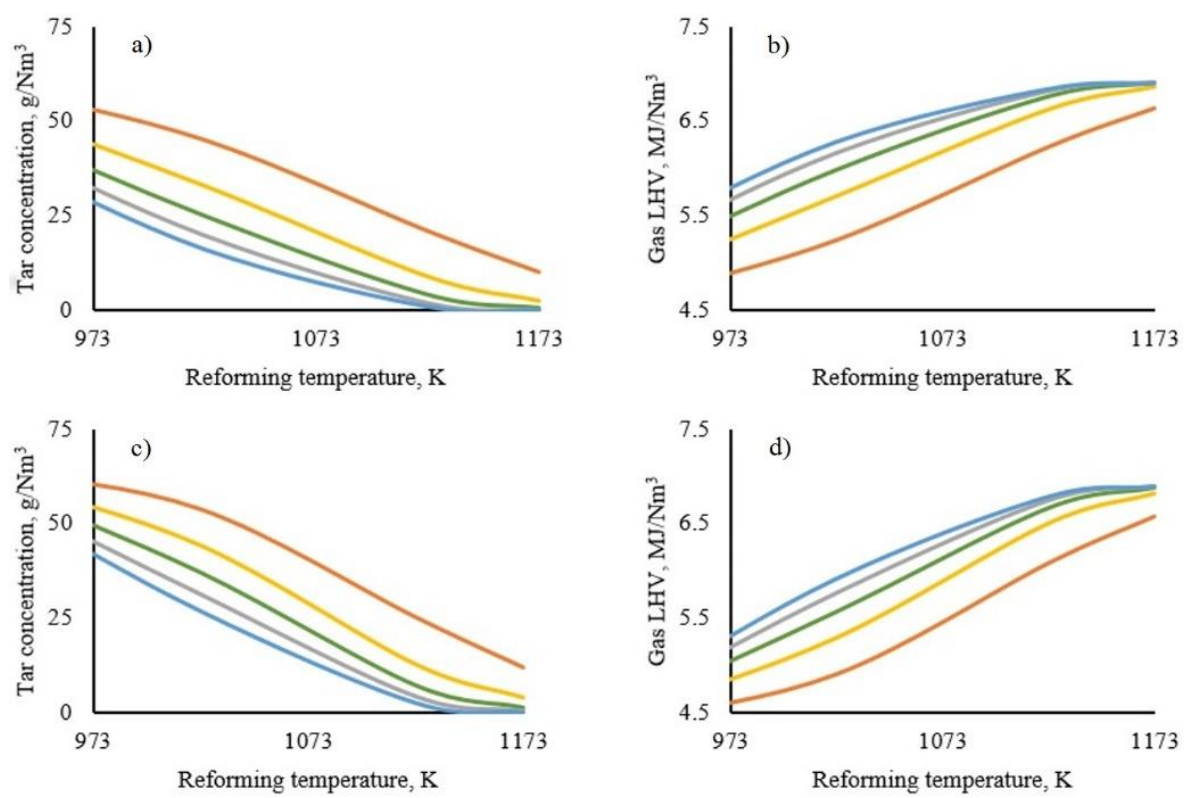

$-0.2 \mathrm{~s}-0.4 \mathrm{~s}-0.6 \mathrm{~s}-0.8 \mathrm{~s}-1.0 \mathrm{~s}$ 

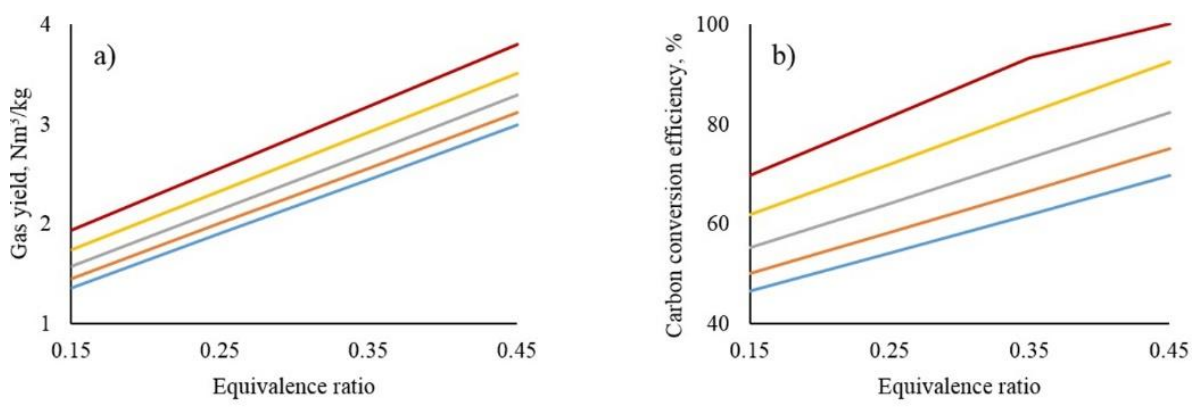

$-923 \mathrm{~K}-973 \mathrm{~K}-1023 \mathrm{~K}-1073 \mathrm{~K}-1123 \mathrm{~K}$

Figure 10. a) Gas yield and b) Carbon Conversion Efficiency (CCE) provided by the gasifier as a function of temperature and equivalence ratio. 


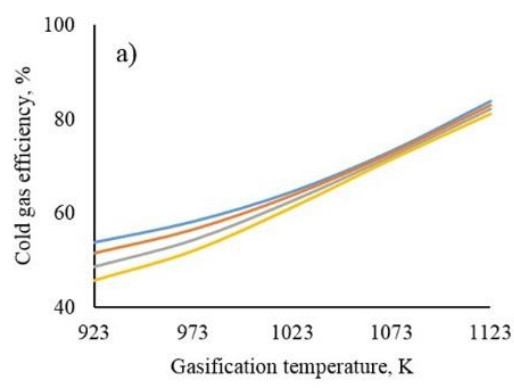

$-0.15-0.25-0.35-0.45$
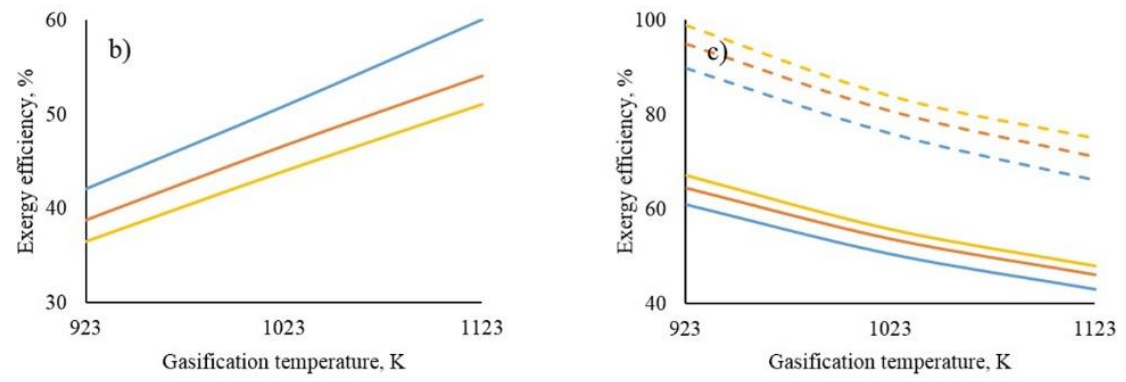

$-\mathrm{ER}=0.25-\mathrm{ER}=0.35-\mathrm{ER}=0.45$

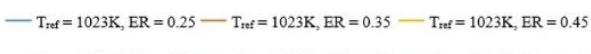

Figure 11. (a) Cold gas efficiency, (b) gasification exergy efficiency and (c) reforming exergy efficiency. 

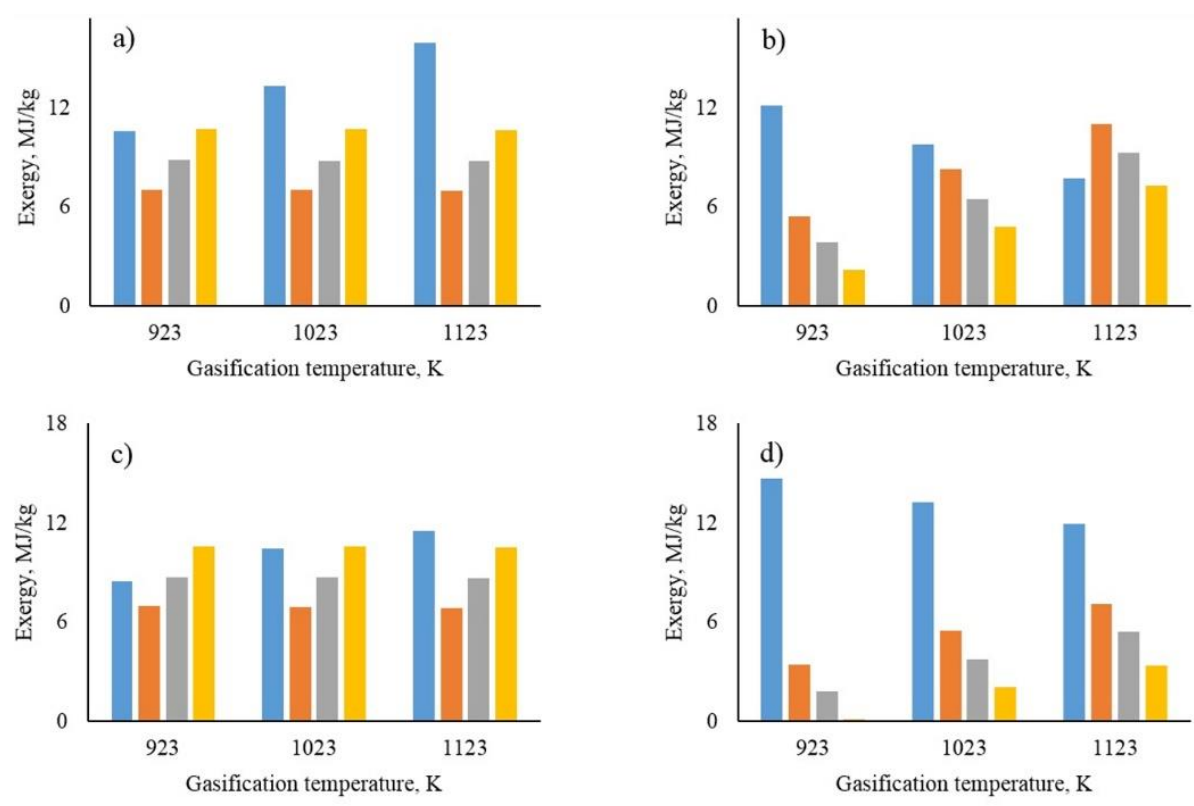

" Gasification " Reforming at $923 \mathrm{~K}$ " Reforming at $1023 \mathrm{~K}$ " Reforming at $1123 \mathrm{~K}$

Figure 12. Total ( $a$ and $c$ ) and destroyed ( $b$ and d) exergies calculated at the outlet of the gasifier and the reformer at different temperatures. The equivalence ratios are 0.15 for $\mathrm{a}$ and $\mathrm{b}$ and 0.45 for $\mathrm{c}$ and $\mathrm{d}$. 


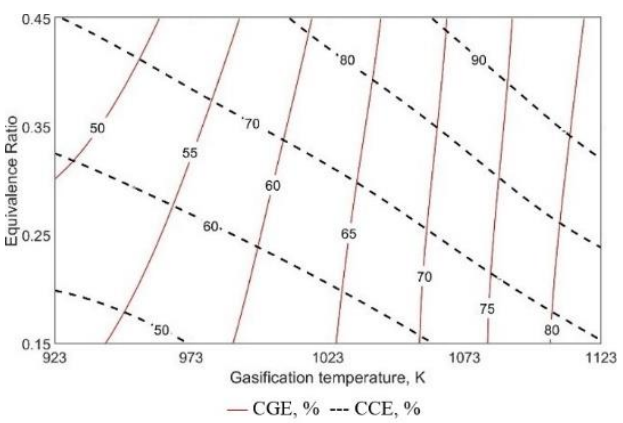

Figure 13. Effect of the gasification temperature and equivalence ratio in the CGE and CCE. 

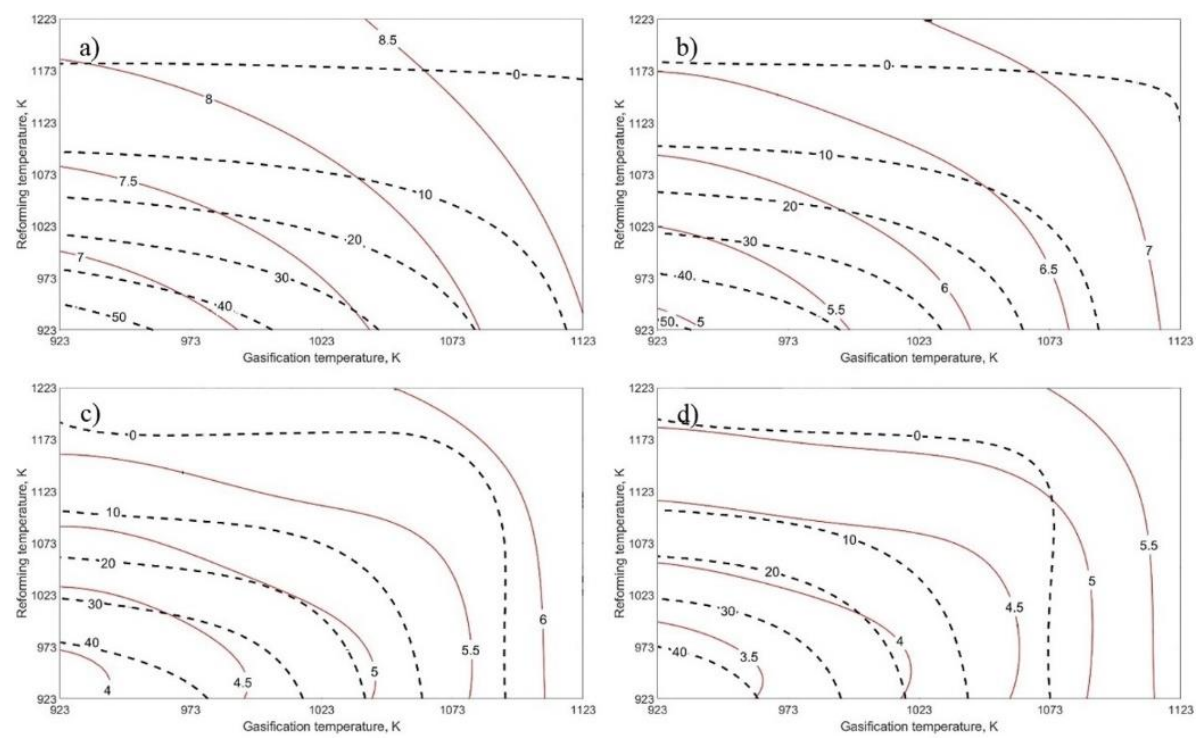

Figure 14. Effect of the gasification and reforming temperatures in LHV of the syngas and the tar contents, when gasifying at an equivalence ratio of a) 0.15 and b) 0.25 . 


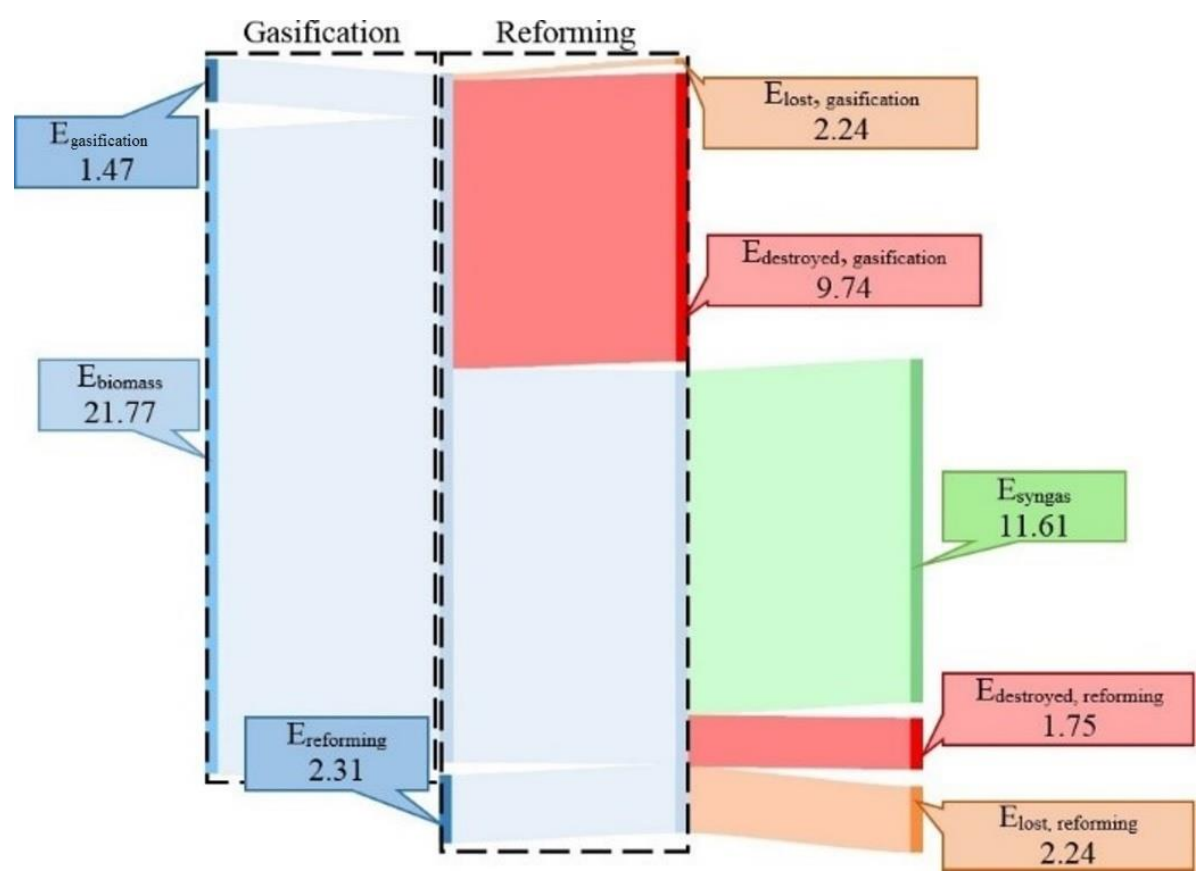

